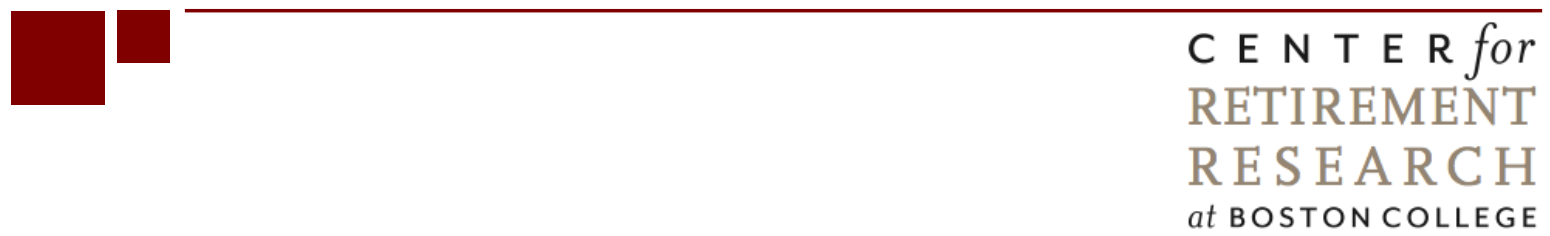

\title{
GREAT RECESSION-INDUCED EARLY CLAIMERS: WHO ARE THEY? HOW MUCH DO THEY LOSE?
}

\author{
Matthew S. Rutledge and Norma B. Coe
}

CRR WP 2012-12

Date Released: April 2012

Date Submitted: March 2012

\author{
Center for Retirement Research at Boston College \\ Hovey House \\ 140 Commonwealth Avenue \\ Chestnut Hill, MA 02467 \\ Tel: 617-552-1762 Fax: 617-552-0191 \\ http://crr.bc.edu
}

Matthew S. Rutledge is a research economist at the Center for Retirement Research at Boston College (CRR). Norma B. Coe is associate director for research the CRR. The research reported here was performed pursuant to a grant from the Russell Sage Foundation. The findings and conclusions expressed are solely those of the authors and do not represent the views of the Russell Sage Foundation or Boston College. The authors would like to thank Kendrew Wong, Mashfiqur Khan, and Lauren Hoehn for excellent research assistance. The authors would also like to thank Alicia H. Munnell, Anthony Webb, Steven A. Sass, Andrew D. Eschtruth, Richard W. Kopcke, William Carrington, and APPAM participants for their comments. All errors are their own.

Corresponding author: Matthew S. Rutledge, Center for Retirement Research at Boston College, Hovey House, 258 Hammond St., Chestnut Hill, MA 02467; Tel: (617) 552-1874; Fax: (617) 552-0191; e-mail: Matthew.Rutledge@bc.edu

(C) 2012, Matthew S. Rutledge and Norma B. Coe. All rights reserved. Short sections of text, not to exceed two paragraphs, may be quoted without explicit permission provided that full credit, including (C) notice, is given to the source. 


\title{
About the Center for Retirement Research
}

The Center for Retirement Research at Boston College, part of a consortium that includes parallel centers at the University of Michigan and the National Bureau of Economic Research, was established in 1998 through a grant from the Social Security Administration. The Center's mission is to produce first-class research and forge a strong link between the academic community and decision-makers in the public and private sectors around an issue of critical importance to the nation's future. To achieve this mission, the Center sponsors a wide variety of research projects, transmits new findings to a broad audience, trains new scholars, and broadens access to valuable data sources.

\author{
Center for Retirement Research at Boston College \\ Hovey House \\ 140 Commonwealth Avenue \\ Chestnut Hill, MA 02467 \\ phone: 617-552-1762 fax: 617-552-0191 \\ e-mail: crr@bc.edu \\ crr.bc.edu
}

Affiliated Institutions:

The Brookings Institution

Massachusetts Institute of Technology

Syracuse University

Urban Institute 


\begin{abstract}
During the Great Recession, more older workers have claimed Social Security retirement benefits early. This paper addresses two important policy questions: Who are these early claimers? How much retirement income have they lost as a result of claiming early? Using the Health and Retirement Study (HRS) we estimate a discrete-time hazard model that makes claiming Social Security benefits a function of age, personal characteristics, and the national unemployment rate. We project that high unemployment rates during the Great Recession led to a 5-percentage-point increase in the probability of claiming early relative to less severe recessions such as the 2001-2003 downturn, and this increase was nearly uniform across socioeconomic groups. Our estimates also suggest that while the Great Recession did impact the claiming decision, it did not cause a dramatic change in monthly benefits. Those individuals we label as "Great Recession Claimers" - whom we simulate were likely to claim their benefits early during the Great Recession but would not have claimed them in a milder downturn - filed for Social Security only 6 months earlier, on average, than they would have in a minor recession. This modest change in timing reduced their monthly Social Security benefit checks by $\$ 56$, or 4.6 percent of average monthly benefits, and the Social Security replacement rate fell by 1.7 percentage points relative to a more typical recession. The benefit reduction resulted from the combined effect of the actuarial reduction for early claiming and the foregone opportunity to continue working and increase the wage base used for calculating benefits.
\end{abstract}




\section{Introduction}

A record 1.3 million men and 1.9 million women began collecting Social Security benefits in 2009 (Johnson and Mommaerts 2010). This surge was in part due to a demographic shift: the early baby boomers are now eligible for retiree benefits. However, the take-up rate, defined as the number of new claimants at the end of the year as a fraction of eligible individuals who had not claimed at the beginning of the year, also increased. Between 2007 and 2009, the take-up rate rose by 4.6 (3.3) percentage points for men (women), suggesting that older Americans were more likely to claim Social Security, probably due to the economic downturn that caused many seniors to lose their jobs or made it difficult for them to find alternative work.

A sizable literature documents the relationship between employment of older workers and the macroeconomy. Not surprisingly, high unemployment rates are associated with earlier retirement (von Wachter 2007; Hallberg 2008; Coile and Levine 2010). At the individual level, late-career job loss is also associated with early retirement (Chan and Huff Stevens 1999, 2004). An older person experiencing a layoff is more likely to be forced into retirement simply due to an inability to find another job, and if they do find employment, it is likely at a much lower wage (Chan and Huff Stevens 2004). This is true even in non-recessionary periods. Huff Stevens and Chan (2001) find that the employment rate of displaced workers who lose their job after age 55 remains 20 percentage points lower than their non-displaced contemporaries five years later.

In such an environment, Social Security may provide an important safety net for displaced older workers. However, using this "insurance" is not costless to the individual. Earlier claiming leads to permanently reduced monthly retirement benefits - for the rest of the beneficiary's life and for the surviving spouse's life - with an even greater reduction for cohorts born after 1937, for whom early claiming is further from their Full Retirement Age (FRA). While the monthly benefit reduction is actuarially fair on average, the actual decrease in lifetime benefits is a function of the life expectancy of each early claimer relative to the average beneficiary and the ability of the potential claimant to increase his benefits by working longer. Lower Social Security income, potentially combined with an early exit from the labor force, large financial losses in 401(k) plans, and declining home values, may have a large impact on the future economic well-being of these early claimants.

Using the 2000-2008 waves of the Health and Retirement Survey (HRS), we compare the claiming ages of individuals by demographics, income, and job characteristics during different 
points in the business cycle. We use binary response regression models and discrete-time hazard models to test for significant changes in the claiming age due to changes in the macroeconomy. We find that the distribution of claiming ages is sensitive to the unemployment rate: when unemployment is high more people claim as soon as they are eligible. Older potential beneficiaries who refrained from claiming at the Early Eligibility Age (EEA) also claim sooner when unemployment is widespread. Interestingly, we find no evidence that more vulnerable groups are more likely to claim early as the unemployment rate increases.

Using our results, we predict a counter-factual claiming pattern for those individuals who became eligible for Social Security during the Great Recession. Our estimates suggest that the Great Recession induced a 5.6 percentage point increase in the number of early claimers than a mild recession. Those whom we project to claim early in the Great Recession but would not have in a milder recession claim 6 months earlier on average. This small change in the timing of claiming reduces the replacement rate by 1.7 percentage points, or about \$56 per month, representing a 4.6 percent decline in average monthly benefits. Social Security monthly benefits fell for two reasons: the actuarial adjustment for early claiming, and the foregone opportunity to continue working and thereby increase one's wage base used to calculate benefits.

The paper continues as follows. Section 1 discusses the literature on Social Security claiming decisions and the macroeconomy. Section 2 discusses the data and Section 3 presents the empirical model. Section 4 presents the results for the claiming decision and the calculations for how much money is lost when Social Security is used as an income-insurance program. Section 5 concludes and discusses potential direction for future research.

\section{Background and Literature}

A recent flurry of papers has predicted the effect of the Great Recession on retirement behavior. While economic theory predicts that losses in wealth - either due to the housing crisis or the stock market decline - would delay retirement, high unemployment and downturn in the overall economy may lead individuals to retire earlier.

Stock Market. Despite the attention by the popular press, much of the literature to date has estimated that retirement and Social Security claiming decisions are relatively inelastic to stock market returns. Coile and Levine (2006) use the stock market boom of the 1990s to test whether stock exposure and retirement during a stock boom or bust are correlated and find no 
evidence of a relationship. Gustman, Steinmeier, and Tabatabai (2010) use a structural model of retirement and saving to simulate the effect of a stock market decline on retirement decisions, independent of other changes in the macroeconomy. Their estimates suggest that the average retirement age would increase by only 1.5 months due to the stock market decline of 2008-2009. The small effect is largely due to how few people respond; they find that less than 10 percent of the population delayed retirement at all due to the decline in the stock market. Near-retirees are somewhat sheltered from the decline because of their relatively limited exposure to the stock market and the relative prevalence of defined benefit pension coverage.

Housing Market. While housing makes up the bulk of most near-retirees' portfolios, economic theory predicts that retirement decisions should be relatively inelastic in response to changes in the housing market. First and foremost, households do not routinely consume their housing wealth in retirement. Venti and Wise (2004) find that most households sell their homes only after experiencing a shock such as the death of a spouse or a nursing home entry. Coile and Levine (2011b) find little evidence of a retirement response to the housing market fluctuations associated with the Great Recession.

Labor Market. Labor market conditions are likely the most important factor in the Great Recession's impact on retirement. Job loss is not uncommon among older workers as of late (Farber 2008, Munnell et al. 2006). The literature tends to agree that retirement transitions are cyclical (Coile and Levine 2007, von Wachter 2007, Hallberg 2008, Friedberg et al. 2008, and Munnell et al. 2008). Munnell et al. (2009) highlight the myriad reasons why older workers may experience the Great Recession differently from older workers in prior recessions, including decreasing defined benefit pension coverage and declining job tenure. However, they may be less responsive due to the removal of the Social Security earnings test, increased educational attainment, declines in retiree health insurance coverage, and the decline in the physical nature of jobs.

Coile and Levine (2011a) use 30 years of Current Population Survey data to estimate the reduced-form relationship between the macroeconomy and retirement. They find that a 1percentage-point-increase in the unemployment rate increases the number of 62- to 64-year-olds and 65- to 69-year-olds who are out of the labor market by 1 percentage point. This effect is strongest among the low-educated, lending support to the hypothesis that Social Security acts as income insurance during bad economic times. They find a differential effect of the 
macroeconomy on receiving Social Security benefits by age: 62- to 64-year-old workers are more likely to receive Social Security benefits in response to unemployment than the 65- to 69year-olds.

Additionally, Coile and Levine (2011a) estimate the impact of the unemployment rate around the time of retirement on a sample of men age 70-79. Their estimates suggest that a 1percentage-point increase in the unemployment rate at ages 62-64 reduces Social Security income by 0.4 percent. For the marginal early claimants, however, their estimates for the reduction in Social Security benefits are rather high - 42 percent for high school drop outs and 53 percent for high school graduates - warranting a second look.

Great Recession as a Whole. Coile and Levine (2011b) predict that the increase in retirement due to the higher unemployment rate will be 50 percent larger than the decrease in retirement due to the stock market and housing crashes. Their prediction seems to hold. While the number of Americans age 62 rose 20 percent between 2008 and 2009, the number of Social Security retirement benefit awardees age 62 rose by 27 percent for men. Figure 1 illustrates the relationship between the percent of the total 62-year-old population claiming at age 62 from 2003-2010 (solid line), and the unemployment rate for the same period (dashed line). The spike in claiming in 2009 is obvious, but it does not continue through 2010 even though the unemployment rate remained high over the same period. This pattern may suggest that retirement decisions are not based solely on the current unemployment level, but also on where the business cycle is: peak, trough, or recovery. We will test for this potentially important lag in our specifications.

\section{Data}

In order to measure the impact of the unemployment rate on retirement claiming, we use the HRS, a panel survey of older Americans conducted by the University of Michigan. We use the 1996-2008 survey waves. Our sample includes three cohorts: the original HRS (birth years 1931-1941), War Babies (1942-1947), and Early Baby Boomers (1948-1953). We examine Social Security claiming decisions biannually starting with the 1998 wave, though we also use the 1996 wave to gather information on some respondents before they turned 62.

The sample is comprised of respondents between ages 62 and 70 during the 1998-2008 waves. We match this sample to the restricted Summary Earnings File, made available by the 
Social Security Administration (SSA). The earnings file includes all Social Security covered earnings between 1951 and the last time the respondent gave permission to match to the restricted data. ${ }^{1}$ The administrative data allow us to determine, first, whether the individual is eligible for Social Security retirement benefits and, if he is, to calculate the benefit to which he is entitled. $^{2}$

We exclude individuals who report receiving Social Security Disability Insurance (SSDI), as well as those who report receiving any public disability benefits and also have accumulated enough work experience to qualify for SSDI. ${ }^{3}$ SSDI beneficiaries are automatically rolled into retirement benefits at the FRA, so their retirement benefit claiming date is predetermined and will not respond to macroeconomic conditions.

We model the decision to claim Social Security retirement benefits. The dependent variable in each regression derives from the self-reported age at which the individual begins receiving Social Security retirement benefits. ${ }^{4}$ We exclude those who report receiving Social Security benefits before 61 years and 9 months; ${ }^{5}$ this is likely due to reporting error or to survivor benefits. We also exclude those who report receiving Social Security retirement benefits but do not report the age at which they first received them. The final sample for the hazard model consists of 3,522 individuals eligible for retirement benefits and observed between ages 61 years and 9 months and 70 years (Table 1), including 3,050 who report claiming at some point between 62 and 70. The sample for the probit model that examines the decision to claim at or around age 62 further restricts the sample to the 3,237 respondents observed turning 62 .

\footnotetext{
${ }^{1}$ Approximately 70 percent of the respondents have given permission. Previous work has concluded that using the matched sample does not introduce bias (Kapteyn et al. 2006).

${ }^{2}$ A worker is "fully insured" for Social Security retirement benefits if he earns at least 40 "work credits" after age 21. A work credit proxies for the number of calendar quarters during which the worker earned at least a minimum level of earnings, without requiring quarterly income reporting to SSA. The minimum earnings per work credit is adjusted each year; in 2010, a worker earned one work credit for every $\$ 1,120$ in earnings, up to four credits per year.

${ }^{3}$ HRS asks if the respondent receives income from SSDI or Supplemental Security Income (SSI), without making a distinction between the two. A follow-up question attempts to determine whether the individual received benefits from SSDI, SSI or both. We exclude those who report receiving only SSDI. We also exclude those who have sufficient work credits to qualify for SSDI, and those whose earnings records have too many years with missing earnings to determine whether they are eligible.

${ }^{4}$ The HRS is not matched to the SSA's Master Beneficiary Record, so we must rely on self-reported claiming age.

${ }^{5}$ For most of the analysis, we consider those who report that they first received benefits in the three months before their $62^{\text {nd }}$ birthdays as claiming at exactly age 62. These individuals may have filed early, but receive their first payment only in the month of their birthday.
} 


\section{Empirical Methodology}

We estimate the effect of the national unemployment rate on Social Security retirement claiming using two different models: (1) a probit regression of claiming at age 62 and (2) a hazard model for claiming in each month from ages 62 to 70 . The first model directly examines the effect of the unemployment rate on claiming benefits as early as possible. The second model enables us to trace out the full pattern of Social Security retirement claiming between 62 and 70, which allows for estimating the effect of unemployment-rate dynamics on expected lifetime Social Security income.

The first model estimates the effect of the unemployment rate on the probability of claiming between age 61 and 9 months and age 62 and 2 months:

$$
\text { Claim at } 62_{i}=\Phi\left(\alpha_{0}+\alpha_{1} U_{62}+\alpha_{2} U_{61}+\alpha_{3} X_{i}+\alpha_{4} U_{62} X_{i}+\varepsilon_{i}\right)
$$

where $\Phi$ is the standard normal cumulative distribution. ${ }^{6}$

The explanatory variable of interest is $U_{62}$, the three-month rolling average of the U.S. unemployment rate six months before individual $i$ 's $62^{\text {nd }}$ birthday. ${ }^{7,8}$ We expect the marginal effect of claiming with respect to the unemployment rate to be positive. Because we also are interested in how the change in the unemployment rate affects the claiming decision when holding the level fixed, we include the three-month average unemployment rate from one year ago, $U_{61} \cdot{ }^{9}$

\footnotetext{
${ }^{6}$ In this regression, we exclude individuals who were last interviewed before age 62 and 2 months, as they did not have full opportunity to claim benefits at or around age 62 .

${ }^{7}$ We have experimented with alternative lags for the unemployment rate; the specification including only six- and 12-month lags fit the data best by both the Akaike and Bayesian Information Criteria. Of concern is that the estimated relationship between claiming and the three-month average unemployment rate in the month the individual turns 62 is not statistically significant when included with just the 12-month lag or with both the 6- and 12-month lags. Intuition suggests that six months is an appropriate lag for both voluntary retirement and involuntary separations. Retirement and claiming are not decisions that most workers (who are not laid off) make suddenly, so the unemployment rate around the decision is more relevant than the unemployment rate on one's last day of work. Furthermore, the most common duration of unemployment benefits for workers who leave their jobs involuntarily is six months.

${ }^{8}$ We use the national unemployment rate instead of state unemployment rates because we cannot merge together both the state identifiers and the earnings histories to the HRS for confidentiality reasons.

${ }^{9}$ If an increase in the unemployment rate over the last year leads to an increase in claiming at 62 , as expected, the coefficient on should be negative. To see this, imagine that equation (1) is linear and re-specify to control for the change in unemployment rate instead of the lagged value:
} 
$X$ is a vector of individual-level characteristics that could impact claiming decisions. We chose variables for inclusion in $X$ based on a probit regression of claiming between HRS waves. Besides basic individual characteristics such as race and ethnicity, pension holdings, and pre-62 work status, industry, job tenure at the most recent job, and income quintile, the results from this regression suggest the inclusion of the interaction of marital status with gender, education, wealth quintile, spouse's pre-62 work status and whether the spouse has reached 62 or FRA. We also include an indicator variable for whether $i$ reports at least two limitations in questions regarding Activities of Daily Living and a measure of $i$ 's subjective probability of living to age 75 relative to the prediction from actuarial tables. ${ }^{10}$ All variables in $X$ are also interacted with $U_{62}$, to allow for heterogeneity in claiming behavior at different levels of the unemployment rate.

The hazard model estimates the probability of claiming Social Security retirement benefits $t$ months after one's $62^{\text {nd }}$ birthday, conditional on not having claimed in previous months:

$$
\begin{aligned}
h_{i t} \equiv \text { Claim }_{i t} \mid & S_{i t} \\
= & \Phi\left(\beta_{0}+\beta_{1} U_{t}+\beta_{2} U_{t-12}+\beta_{3} X_{i t}+\beta_{4} X_{i t} U_{t}+\tau_{t}+\tau_{t} U_{t}+v_{i}\right)
\end{aligned}
$$

where $S_{i t}$ is the survival function, i.e., the probability that $\operatorname{Claim}_{i s}=0$ for all $s<t$. Because the data include only the month of claiming, rather than the exact date, we estimate the discretetime hazard model with a probit regression, with indicator variables for each month since 62, $\tau$, to allow for non-linear duration dependence. ${ }^{11}$ The hazard model also includes interactions between the current unemployment rate (averaged over the previous three months), $U_{t}$, and all of the (possibly time-varying) personal characteristics in $X,{ }^{12}$ as well as the month dummies.

\footnotetext{
Assume that, so that a one percentage point increase in the one-year change in the unemployment rate increases the probability of claiming at age 62 by . Rearranging this new specification, however, the effect of the lagged unemployment rate is (while the full effect of the level of unemployment rate on claiming is ). Intuitively, for a given level of current unemployment rate, as the unemployment rate one year ago increases, the change in unemployment rate decreases; therefore, given the assumption of a positive correlation between the change in the unemployment rate and claiming, the probability of claiming at 62 decreases as well. Either specification is equally valid but, given our focus on the level of unemployment, equation (1) is preferred.

${ }^{10}$ The ratio of the subjective probability of living to 75 to the objective probability is calculated by RAND based on self-reported data and the life tables adjusted by age and gender. The ratio ranges from 0 to 2 . This is equal to one if their subjective probability matches the actuarial prediction. Values less than one represent pessimism or private information about poor survival prospects, while values greater than one suggest the person is optimistic or has reason to believe he will live longer than average.

${ }^{11}$ To reduce the number of covariates, the month fixed effects are grouped in two-month bins.

${ }^{12}$ The time-varying individual characteristics - marital status, income and wealth quintiles, pension holding, spouse work status and age, ADLs, and probability of living until age 75 - vary only at each new HRS interview. We hold
} 
For both models, we report the marginal effect of each variable, rather than the coefficient, because of the nonlinearity of the probit model. The marginal effect is the derivative of claiming probability with respect to a variable evaluated at that variable's mean. We use the Delta Method to calculate standard errors. We also report interaction effects and standard errors that account for the nonlinearity (Ai and Norton 2003).

We then use the estimate from the fully interacted hazard to forecast the effect of the high unemployment rates experienced during the Great Recession on early claiming behavior. We use our sample of individuals born between 1928 and 1946 as a model for those who turned 62 between January 2009 and December 2010 by randomly assigning each person a birth month between January 1947 and December $1948 .{ }^{13}$ We then predict the probability of individual $i$ claiming Social Security retirement benefits in specific month $t, p_{i t} \equiv h_{i t} S_{i t}$, based on the hazard estimates. We calculate $p_{i t}$ using three different patterns for the national unemployment rate. For the Great Recession scenario, we use the actual rates from 2008 through 2011. The Minor Recession scenario assumes a recession with the exact same shape as the mild 2001-2003 recession; specifically, we add the difference between the pre-recession unemployment rate and the actual unemployment rate in the $\mathrm{n}^{\text {th }}$ month of the 2001-2003 recession to the unemployment rate before the Great Recession. ${ }^{14}$ The No Recession scenario fixes the 6-month-lagged unemployment rate at 4.9 percent, the average unemployment rate between February and April 2008, which were the last months before the seasonally adjusted unemployment rate began to increase. ${ }^{15}$ For each scenario, we fill in the unemployment rate for 2012 through 2020 with the Social Security Administration forecast (Social Security Trustees 2011).

two other potentially time-varying characteristics, work status and industry, constant at their pre-62 values. We also add the interaction between pre-62 work status and current wealth quintile.

13 The simulations assume that our hazard model sample is representative of a similarly-defined group from the 1947-1948 cohorts. Given changes in demographics and the structure of the labor market across cohorts, this could be a problematic assumption, and in future work we plan to weight the 1928-1946 cohorts to better represent the younger group. On the other hand, very few of the interaction effects with the unemployment rate are statistically significant; thus, while the level of benefits and the percent claiming early may be biased under any particular macroeconomic scenario, there is no reason to expect differential bias between counterfactual exercises.

${ }^{14}$ For example, the three-month running average of the national unemployment rate in the 12th month of the 20012003 recession, March 2002, was 5.7 percent, 1.5 percentage points higher than the pre-recession baseline of 4.2 percent (March 2001). The counterfactual unemployment rate for the 12th month of the Great Recession, April 2009, is therefore 6.4 percent, or 1.5 percentage points greater than the pre-Great Recession baseline of 4.8 percent, substantially lower than the actual (rolling average) unemployment rate in April 2009 of 8.6 percent.

${ }^{15}$ Given that the last recession had ended more than six years prior to April 2008 and that the average post-war business cycle lasts just under five years, the Minor Recession counterfactual is more realistic than the No Recession scenario. 
One way to think about the predicted probability of claiming early is as a proxy for a latent continuous index of the utility from claiming early; if the index exceeds a particular idiosyncratic threshold, that person claims early. Actual claiming behavior may deviate from the predicted probability, of course, but if our model captures the key variables that affect an individual's decision to claim benefits, the deviation will be essentially random. To classify individuals in our sample by their predicted early claiming behavior, we first create their idiosyncratic threshold for claiming by drawing a random number from the uniform distribution $[0,1]$ for each person, and compare that number to the predicted probability of claiming at age 62 in the Great Recession ( $p_{i t}^{G R}$ ) and Minor Recession $\left(p_{i t}^{M R}\right)$ scenarios. If the random number is below both $p_{i t}^{M R}$ and $p_{i t}^{G R}$, the model predicts that the individual claims early in both scenarios; we classify these individuals as All-Recession Claimers. If the random number is above both predicted probabilities, the model predicts that the individual does not claim early in either scenario; we classify these individuals as Never Early Claimers. We define a third group, Great Recession Claimers, whose random number is above $p_{i t}^{M R}$ but below $p_{i t}^{G R}$; these individuals are predicted to change their behavior under the Great Recession scenario, because the increase in the predicted probability lifts the individual over their individual-specific threshold.

We then project how early claiming affects expected monthly Social Security benefits and the replacement rate. Beneficiary $i^{\prime \prime}$ 's potential benefit $t$ months after turning 62 is $\hat{p}_{i t} * B_{i t}$, where $\hat{p}_{i t}$ is the predicted probability of claiming in that particular month based on the estimation of equation (2) and benefit $B_{i t}$ adjusts his primary insurance amount at age 62 by the early retirement reduction or delayed retirement credit. ${ }^{16}$ His expected benefit is the sum of $\hat{p}_{i t} * B_{i t}$ over the months between his $62^{\text {nd }}$ and $70^{\text {th }}$ birthdays, and his replacement rate is the ratio of the expected benefit to his Average Indexed Monthly Earnings (AIME) as of age $62 .{ }^{17}$ In the calculation of expected benefit and replacement rate, we allow the potential claimant to continue working as long as he has not claimed his benefit, so that $B_{i t}$ increases over time; in this case, we

\footnotetext{
${ }^{16}$ The Social Security retirement benefit is the Primary Insurance Amount (PIA), reduced by 5/12ths of a percent for every month that is at least three years before FRA, and by 5/9ths of a percent for every month before the FRA but within three years. Beneficiaries claiming after FRA earn the PIA plus an additional credit for each month they delay; the credit depends on i's birth year, ranging from 4 percent for the 1928 cohort to 8 percent for those born after 1942. The benefit reductions and credits are calculated so that the benefit is actuarially fair for the average beneficiary, though the optimal claiming age varies with the individual's monetary needs and health (Coile, Diamond, Gruber, and Jousten 2002).

${ }^{17}$ We adjust individual $i$ 's earnings history to reflect his hypothetical birth month. For example, if the individual was actually born in 1937 but is randomly assigned a birth month of January 1948 (11 years later), we convert his 1955 earnings to 1966 dollars, his 1956 earnings to 1967 dollars, and so on, using the NAWI.
} 
project the individual's earnings to grow from his age-60 level at the rate of the national average wage index (NAWI) for each month without claiming, which increases potential retirement benefits. ${ }^{18}$

\section{Results}

We are ultimately interested in the change in Social Security claiming behavior due to higher unemployment rates starting in 2008. Figure 1 suggests that early claiming deviated from a secular downward trend in the percentage of older Americans claiming benefits at their ERA, but administrative tabulations to date have provided little information on the characteristics of early claimers. The HRS is ideal for this purpose, but data for the Great Recession period are still preliminary. We thus analyze the potentially heterogeneous response of older HRS cohorts to changes in the unemployment rate around the time of their $62^{\text {nd }}$ birthdays, and then use these estimates to project claiming behavior for the cohorts that reached ERA beginning in 2009.

First, we compare Social Security beneficiaries by the age that they claim. Table 2 compares the characteristics of HRS respondents from the wave immediately prior to turning 62 by the timing of their Social Security retirement benefit claim, regardless of what year they claimed: within three months of age 62, after age 62 but before their FRA, and at or after their FRA. Early claimers are less educated, have lower incomes, are less healthy on average than those who delay claiming, and are less likely to live until age 75 . The household of an average early claimer earns $\$ 62,500$ and has accumulated $\$ 436,000$ of wealth before age 62 , compared with nearly $\$ 103,000$ in income and $\$ 663,000$ in wealth for those who delay claiming until their FRA or later. More than 60 percent of early claimers have a high school education or less, compared with 42 percent of those who wait until their FRA; only 17 percent of early claimers have a college degree, compared with 37 percent of FRA claimers. Early claimers are more likely to have multiple limitations on their Activities of Daily Living (ADL) than those who delay claiming. Interestingly, early claimers are more likely both to have no pension coverage (31 percent, compared with 17 percent of FRA claimers) or to have only a defined benefit (DB) pension (19 percent versus 10 percent), while FRA claimers overall are more likely to have DB pensions, including individuals with both DB and defined contribution plans.

\footnotetext{
${ }^{18}$ If reported earnings grow after age 60 by more than NAWI, we use the higher amount.
} 
Table 3 compares early claimers during the late-1990s expansion, the recession of the early 2000s, and the recovery of the mid-2000s. Individuals who are early claimers during the recovery period are more likely to be in poor health, in terms of both their ADL prevalence and their lower self-reported life expectancies. They are less likely to be working full-time and less likely to have a DB plan (including a mixed plan). At the same time, they are more educated than individuals who claimed early during other points in the business cycle. Early claimers during the 2001-2003 recession tended to have lower income, less wealth, and lower education levels, and they are less likely to be married compared to early claimers during the recovery. This suggests that those hardest hit by recessions are most likely to use Social Security as their income-insurance policy.

The probit regression results in the first column of Table 4 affirm the claim that a higher unemployment rate is associated with more potential Social Security recipients claiming retirement benefits as soon as they become eligible. A 1-percentage-point-increase in the unemployment rate before the respondent turns 62 is associated with a 3.1 percentage point increase in the probability of claiming right at age 62, an effect that is statistically significant at the 90 percent confidence level. Further, the marginal effect of the three-month average unemployment rate, lagged by twelve months, on claiming at 62 is negative and significant, indicating that an increase in the unemployment rate, holding the current unemployment rate fixed, also is associated with an increased probability of receiving benefits starting at 62 .

Most of the other estimated effects are in the expected direction. Those working full time at the time of their pre-62 HRS interview are 35 percent less likely to claim at their $62^{\text {nd }}$ birthday than those who were not working, while part-time workers are 14 percent less likely; both effects are statistically significant. College graduates and those with working spouses are also less likely to claim early, while workers in the manufacturing industry are more likely. Early claiming decreases with income in a linear fashion, but the pattern is more surprising for wealth - those in the highest and, even more so, the second-highest wealth quintiles are more likely to collect Social Security benefits as early as possible.

The magnitude of the marginal effects is similar in the fully interacted model, though the standard error on the current unemployment rate increased sharply. The model allows for heterogeneity in the relationship between the unemployment rate and early claiming, but the interaction effect is statistically significant for only one variable: as the unemployment rate 
increases, married individuals increase their probability of claiming early. On the whole, the interaction coefficients are not jointly significantly different from zero $(p=0.33)$, and a likelihood ratio test fails to reject the null hypothesis that the two models are equivalent $(\mathrm{p}=$ 0.39). ${ }^{19}$

Figure 2 plots the predicted probability of claiming benefits at or around one's $62^{\text {nd }}$ birthday over time (solid line), given the unemployment rates six and 12 months before the given month. The predicted probability of early claiming was relatively low during the expansions of the late 1990s and the mid-2000s but increased over the course of 2001-2003 as the U.S. macroeconomy reached its trough.

The values to the right of the vertical line in Figure 2 use the national unemployment rate from 2009 through 2011 to calculate out-of-sample predictions for the probability of claiming at 62. ${ }^{20}$ As with the 2001 recession, the model predicts a sharp increase in early claiming in 2008 and 2009, exceeding 45 percent of the sample in mid-2009; this increase matches the pattern in the administrative data (Figure 1). Interestingly, the model also predicts a subsequent sharp decline in early claiming, with the predicted early claiming rate falling to new lows in early 2011. This decline is entirely due to the legacy of the high unemployment rate looking back 12 months, which has a large negative marginal effect. While the predicted probability also declines, even as the 2002-2003 “jobless recovery” continued, the unprecedented persistence of high unemployment in the current downturn makes prediction difficult; indeed, the administrative data show a small decline in the proportion of 62-year-olds collecting Social Security retirement benefits, though not to the extent predicted by the model.

Hazard Model. The hazard model estimates the effect of the same variables on claiming not just at age 62, but in each month after one became eligible to claim. Although the model's outcome variable is different, the results are similar to the probit model: a higher unemployment rate makes claiming in any month more likely, especially if the unemployment rate had increased during the past year (Table 5). A 1-percentage-point-increase in the unemployment rate increases the probability of claiming in the current month by one-third of a percentage point, out of a claiming probability in the average month of 3.8 percent. Non-whites, Hispanics, college

\footnotetext{
${ }^{19}$ We estimate both the age-62 probit (Table A1) and the hazard model (Table A2) separately for men, single women, and married women, and the results are substantively similar.

${ }^{20}$ We calculate the predicted probability using the non-interacted model. All variables other than the unemployment rate and its lag are held constant at their respective means.
} 
graduates, those with longer tenures in their most recent job or with higher incomes, and those who feel they were likely to live to age 75 are more likely to delay Social Security benefits. Part-time workers are more likely to claim than non-workers, and those with access to pensions regardless of whether the plan is a defined benefit or defined contribution plan - claim earlier than those without pension coverage. Finally, few potential beneficiaries continue to delay claiming after they reached their FRA, despite the ability to permanently increase benefits; the largest magnitude among all of the explanatory variables is the strongly statistically significant marginal effect for an indicator of whether the current month is at or after the individual's FRA.

As with the probit model, the results of the hazard model that includes the interaction of all variables (other than the lagged unemployment rate) with the current unemployment rate results are largely equivalent to the non-interacted model, though the likelihood ratio rejects the equivalence of the two models due to the large sample size. Only a few variables have statistically significant interaction effects; these suggest that as the unemployment rate increased, individuals in the second-from-bottom income quintile (compared with those in the middle quintile), some college experience but no degree, and married individuals with a spouse over the FRA are quicker to claim benefits, while those who are working in the last interview before turning 62 are more likely to delay.

Figure 3 plots the predicted probability of claiming benefits by age from 1998 through 2011, using the hazard model estimates. The probability of claiming before one's $63^{\text {rd }}$ birthday (solid line) exhibits nearly the same pattern as shown in Figure 2, as expected. The probability of claiming between one's $65^{\text {th }}$ and $66^{\text {th }}$ birthdays, which captures all of the birth cohorts' FRAs, also increased slightly in recessions. Claiming at older ages also increases, but with a long lag after the start of the recession.

Costs of Claiming Early. Using our hazard model estimates, we forecast Social Security claiming from 2009 through 2010, using the actual unemployment rate, which varied between 4.9 and 10.0 percent, and two counterfactual scenarios.

Tables 6 through 9 and Figures 4 and 5 summarize the results of the simulation of claiming behavior among the 1947-1948 cohorts, based on the characteristics of the hazard estimation sample. We project that 46.5 percent of those turning 62 in 2009 and 2010 claimed their benefits within three months of their $62^{\text {nd }}$ birthday, given the unemployment rates during 
these years. ${ }^{21}$ If the unemployment rate instead had followed the trajectory of the mild recession of 2001-2003, 40.9 percent would have claimed benefits at age 62; and if the unemployment rate had remained flat at 4.9 percent (the average between February and April 2008), only 38.3 percent would have claimed around the Early Retirement Age (ERA). The majority of the increase in early claiming is drawn from individuals who otherwise would have claimed benefits between their ERAs and FRAs; the percent of projected claimants at these ages declines by 5.5 percentage points from the minor recession scenario and 7.8 percentage points from the scenario with no recession, while the proportion delaying collecting benefits until after reaching the FRA declines by only 0.1 and 0.3 percentage points, respectively.

The probit and hazard model results in the above section make clear that this increase in the probability of claiming around age 62 is uniform across socioeconomic groups, as few of the interaction effects between unemployment and personal characteristics is statistically significant. Figures 4 and 5 show that all points in the income and wealth distributions, respectively, experience increases in the probability of claiming early between the Great Recession and Minor Recession scenarios. The largest increase in the probability of claiming early is among those in the middle of each distribution, though the differential upward shift in early claiming prevalence at different points in these distributions is not statistically significant. Lower income individuals are more likely to claim benefits early in both scenarios, but since their increase is in line with the rest of the distribution, this should reassure policymakers concerned about disproportionate recession-induced claiming by vulnerable populations.

The statistical insignificance of all but a handful of interaction effects in Tables 4 and 5 indicate that the response to the Great Recession in the predicted probability of early claiming is a nearly uniform 5-percentage-point increase. Table 7, which highlights mean predicted probabilities of claiming early for individuals with particular characteristics, largely confirms this finding. For the majority of demographic groups, the increase in the projected probability of claiming early between the Minor Recession and Great Recession scenarios is between 4 and 6 percentage points. A few differences stand out: the increase for the second-to-bottom income quintile, middle wealth quintile, those with a spouse past his or her FRA, professionals, and high

\footnotetext{
${ }^{21}$ The estimate of 46.5 percent of newly-eligible claiming Social Security benefits is slightly higher than the 42 percent claiming rate in 2009 from the administrative data (Trustees Report 2010). This is likely due to compositional differences in the HRS, who oversample minorities and Floridians. These estimates only apply to our sample since we want to examine longitudinal behavior and we do not re-weight to address the sampling design.
} 
school graduates without college experience have a greater projected response to the higher unemployment rates that occurred during the Great Recession. Hispanics, agricultural workers, and those at either extreme of the wealth distribution had less of a change in their projected early claiming probability.

Nevertheless, even a uniform increase in the probability of claiming benefits could lead some individuals who were previously on the margin to change their behavior and file for benefits. One way to think about the predicted probability of claiming early is as a proxy for a latent continuous index of the utility from claiming early, where the individual claims early if the index exceeds an idiosyncratic threshold. For example, two individuals could both have a latent threshold of 42 percent. Under the Minor Recession scenario, Person A has a predicted probability of claiming early of 30 percent, while Person B has a predicted probability of 40 percent. The statistically insignificant interaction effects in Tables 4 and 5 and the demographic comparisons in Table 7 suggest that both A and B will experience identical 5-percentage-pointincreases in their predicted probability of claiming by changing unemployment rates to Great Recession levels. Their predicted behavior, however, is different: Person A's probability increases to only 35 percent, still below the threshold, while Person B's predicted probability now exceeds the threshold at 45 percent.

Table 8 presents the change in the monthly benefit and replacement rate, separately by whether projected behavior changed between the Minor and Great Recession scenarios. Panel A presents these statistics for all individuals projected to claim early in the Great Recession. We then break this group into its two components, defined by who crosses their idiosyncratic threshold in each scenario. Panel B presents the group of All-Recession Claimers, whom we project to claim benefits early in both the Minor Recession and Great Recession scenarios (85 percent of the Panel A sample). The other group is Great Recession Claimers, whom we project to claim benefits early in the Great Recession but not in the Minor Recession, presented in Panel C (15 percent). Benefits for All-Recession Claimers are 2 to 6 percent lower than for Great Recession Claimers due to their lower average incomes and shorter work histories. The claiming age of the All-Recession Claimers group is projected to have stayed relatively constant, by definition, which also translates into little impact on monthly benefits (\$18 to \$32 per month) and replacement rates (0.6 to 1.1 percentage points) among the macroeconomic scenarios. The Great Recession Claimers, on the other hand, are projected to have received benefits almost 6 
months earlier than if there had been a minor recession and almost 10 months earlier than if there had been no recession. Recession-induced early claiming reduced benefits for this group by an average of \$56 per month, or 4.6 percent, relative to the Minor Recession scenario and \$94 per month, or 7.6 percent, compared to the No Recession scenario. Replacement rates fell almost 2 percentage points, from 43.0 percent of AIME in a milder recession to 41.3 percent under Great Recession unemployment rates, and by more than 3 percentage points from the No Recession scenario.

\section{Conclusions}

We estimate the relationship between the age at which individuals claim Social Security and the U.S. unemployment rate in two different ways: a probit model for claiming at age 62, and a discrete-time hazard model for claiming between the ages of 62 and 70 . We find that individuals are very responsive to labor market conditions, but the response to higher unemployment rates is nearly uniform across socioeconomic groups. We project that the dramatic increase in the unemployment rate during the Great Recession led to 46 percent of newly eligible HRS respondents claiming benefits at their ERA, compared to an early claiming rate of 41 percent if unemployment rates had mimicked the more modest increases from the previous recession.

The recession-induced increase in early claiming reduced monthly benefits by $\$ 56$. This 4.6 percent decrease in monthly benefits reduced the replacement rate by about 1.7 percentage points from its average of 43 percent.

These results suggest that many older individuals - and not just those in vulnerable groups or with lower life expectancy - use the Social Security system as income insurance during downturns. However, while the actuarial reduction in benefits caused by early claiming and the foregone earnings caused by the loss of employment are not costless, the reduction in benefits is relatively modest over the long run.

We also find that not only the level of unemployment but also the location in the business cycle matter - boom, bust, recovery, or downturn. While we do not match the administrative pattern exactly, our model does predict both the peak of early claiming experienced in 2009 and the following decline in early claiming in 2010. Both of these predictions are currently made 
out-of-sample. Future work will include adding the 2010 HRS to the estimation model, which will allow us to improve our model fit.

Interestingly, we also find that, despite the removal of the Social Security earnings test and the addition of actuarially fair delayed claiming credits, very few people delayed claiming past their FRA. Further work could examine how the characteristics of the FRA-age claimers have changed with the increase in the FRA and what factors predict late Social Security claiming. It would also be useful to know what financial incentives might be more effective to delay claiming and if this could impact Social Security's 75-year budget outlook. 


\section{References}

Ai, Chunrong and Edward C. Norton. 2003. "Interaction Terms in Logit and Probit Models." Economic Letters 80: 123-129.

Bosworth, Barry P. and Gary Burtless. 2010. "Recessions, Wealth Destruction, and the Timing of Retirement.” Working Paper 2010-22. Chestnut Hill, MA: Center for Retirement Research at Boston College.

Brown, Jeffrey R., Jeffrey B. Liebman, and Joshua Pollet. 2002. “Appendix. Estimating Life Tables That Reflect Socioeconomic Differences In Mortality” in The Distributional Aspects of Social Security and Social Security Reform, edited by Martin Feldstein and Jeffrey B. Liebman. Chicago: University of Chicago Press.

Chan, Sewin and Ann Huff Stevens. 1999. "Employment and Retirement Following a LateCareer Job Loss.” American Economic Review 89(2).

Chan, Sewin and Ann Huff Stevens. 2004. "How Does Job Loss Affect the Timing of Retirement?” Contributions to Economic Analysis \& Policy 3(1).

Coile, Courtney, Peter Diamond, Jonathan Gruber, and Alain Jousten. 2002. "Delays in Claiming Social Security Benefits,” Journal of Public Economics 84(3): 357-385.

Coile, Courtney and Phillip B. Levine. 2006. "Bulls, Bears, and Retirement Behavior.” Industrial Labor Relations Review. 59(3): 408-429.

Coile, Courtney and Phillip B. Levine. 2007. "Labor Market Shocks and Retirement: Do Government Programs Matter?” Journal of Public Economics 91(10): 1902-1919.

Coile, Courtney and Phillip B. Levine. 2010. "Recessions, Reeling Markets, and Retiree WellBeing.” Working Paper 16066. Cambridge, MA: National Bureau of Economic Research.

Coile, Courtney and Phillip B. Levine. 2011a. "Recessions, Retirement and Social Security.” American Economic Review Papers and Proceedings 101(3): 23-28.

Coile, Courtney and Phillip B. Levine. 2011b. “The Market Crash and Mass Layoffs: How the Current Economic Crisis May Affect Retirement.” The B.E. Journal of Economic Analysis and Policy 11(1): Contributions, Article 22.

Farber, Henry S. 2008. "Job Loss and the Decline in Job Security in the United States." Industrial Relations Section Working Paper 520.

Friedberg, Leora, Michael Owyang, and Anthony Webb. 2008. "Identifying Local Differences in Retirement Patterns.” Working Paper 2008-18. Chestnut Hill, MA: Center for Retirement Research at Boston College. 
Gustman, Alan L., Thomas L. Steinmeier, and Nahid Tabatabai. 2010. "What the Stock Market Decline Means for the Financial Security and Retirement Choices of the Near-Retirement Population.” Journal of Economic Perspectives 24(1): 161-182.

Hallberg, Daniel. 2008. “Economic Fluctuations and Retirement of Older Employees.” Working Paper 2008-2. Uppsala, Sweden: Institute for Labour Market Policy Evaluation.

Huff Stevens, Ann and Sewin Chan. 2001. “Job Loss and Ecomployment Patterns of Older Workers.” Journal of Labor Economics 19(2): 484-521.

Johnson, Richard W. and Corina Mommaerts. 2010. "Social Security Retirement Benefit Awards Hit All-Time High in 2009.” Fact Sheet on Retirement Policy. Washington, DC: The Urban Institute.

Kapteyn, Arie, Pierre-Carl Michaud, James Smith and Arthur van Soest. 2006. "Effects of Attrition and Non-Response in the Health and Retirement Study.” Working Paper WR407. Santa Monica, CA: RAND Corporation.

Munnell, Alicia H., Steven A. Sass, Mauricio Soto, and Natalia Zhivan. 2006. "Has the Displacement of Older Workers Increased?” Working Paper 2006-17. Chestnut Hill, MA: Center for Retirement Research at Boston College.

Munnell, Alicia H., Mauricio Soto, Robert Triest and Natalia Zhivan. 2008. "How Much do State Economics and Other Characteristics Affect Labor Force Participation of Older Workers?” Working Paper 2008-12. Chestnut Hill, MA: Center for Retirement Research at Boston College.

Munnell, Alicia H., Dan Muldoon, and Steven A. Sass. 2009. "Recession and Older Workers.” Issue in Brief 2009-2. Chestnut Hill, MA: Center for Retirement Research at Boston College.

U.S. Social Security Administration. 2002. The Annual Report of the Board of Trustees of the Federal Old-Age and Survivors Insurance and Federal Disability Insurance Trust Funds. Washington, DC: U.S. Government Printing Office.

2011. The Annual Report of the Board of Trustees of the Federal Old-Age and Survivors Insurance and Federal Disability Insurance Trust Funds. Washington, DC: U.S. Government Printing Office.

Von Wachter, Till. 2007. "The Effect of Economic Condition on the Employment of Workers Nearing Retirement Age.” Working Paper 2007-25. Chestnut Hill, MA: Center for Retirement Research at Boston College. 
Figure 1. Percent of 62-year-old Population Claiming Social Security at 62 and the National Unemployment Rate

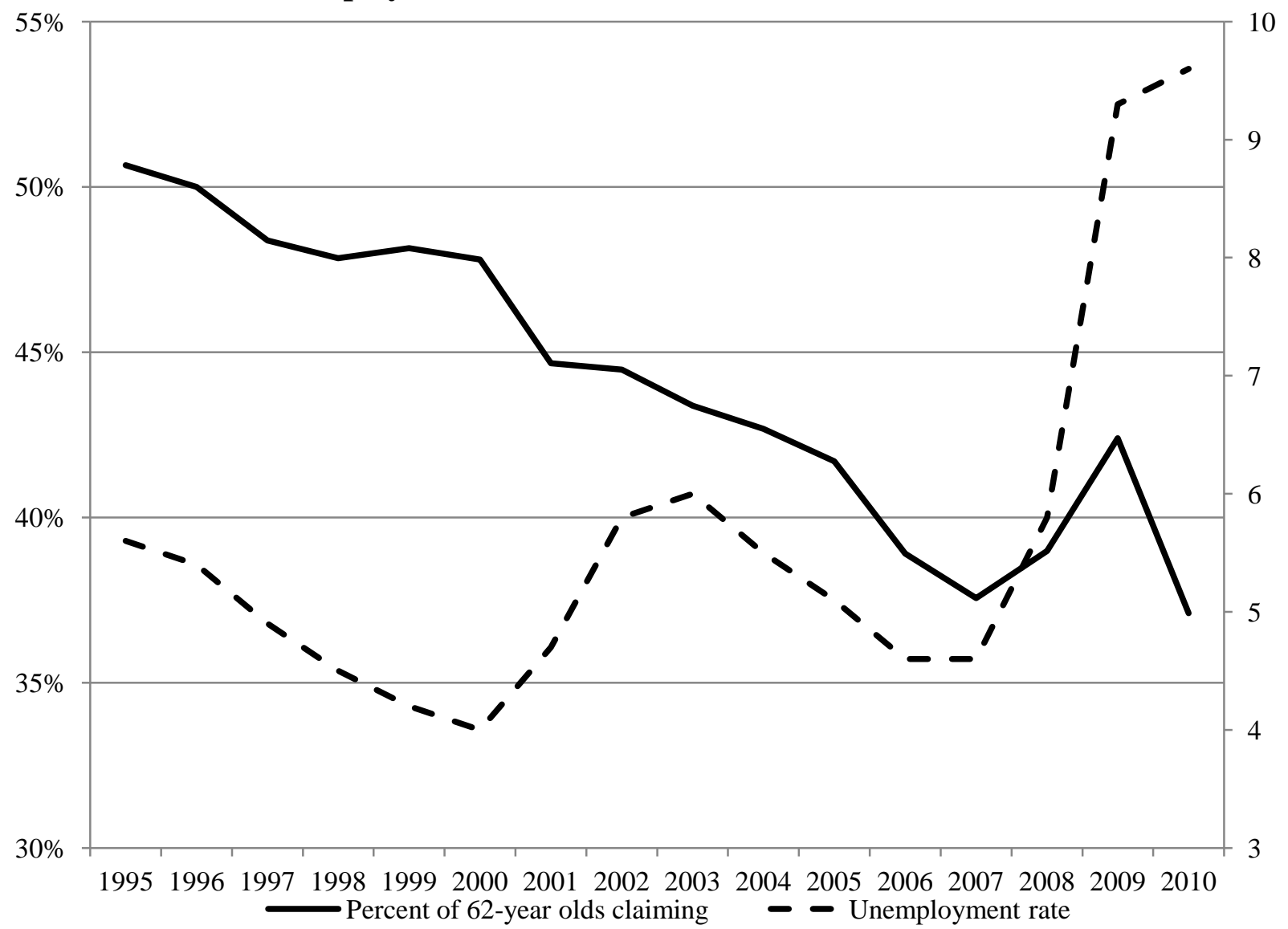

Source: Bosworth and Burtless (2010) and Bureau of Labor Statistics. 
Figure 2. Predicted Probability of Claiming at 62nd Birthday and the National Unemployment Rate

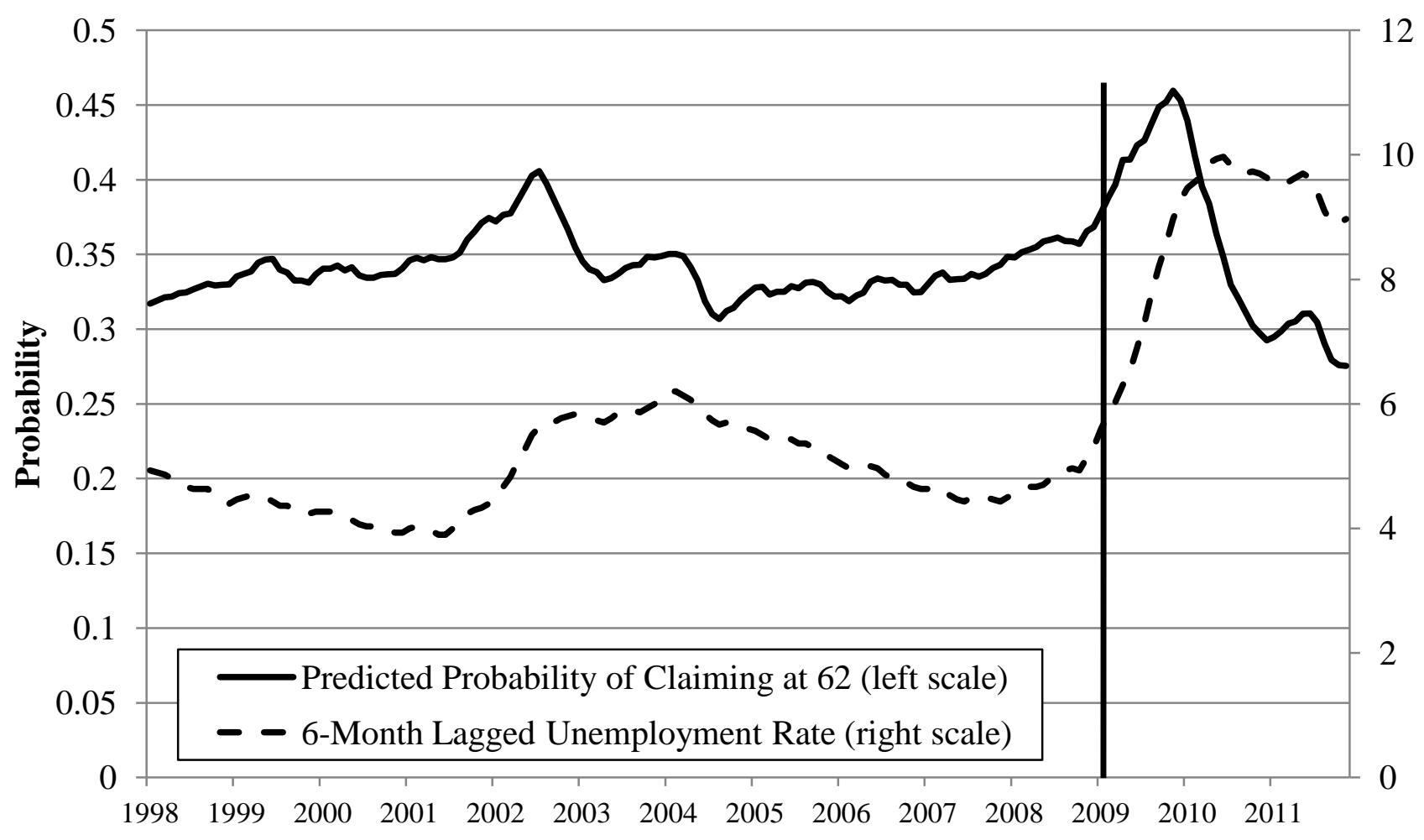

Source: Authors' estimates using Health and Retirement Study 1996-2008. 
Figure 3. Predicted Probability of Claiming by Age and the National Unemployment Rate

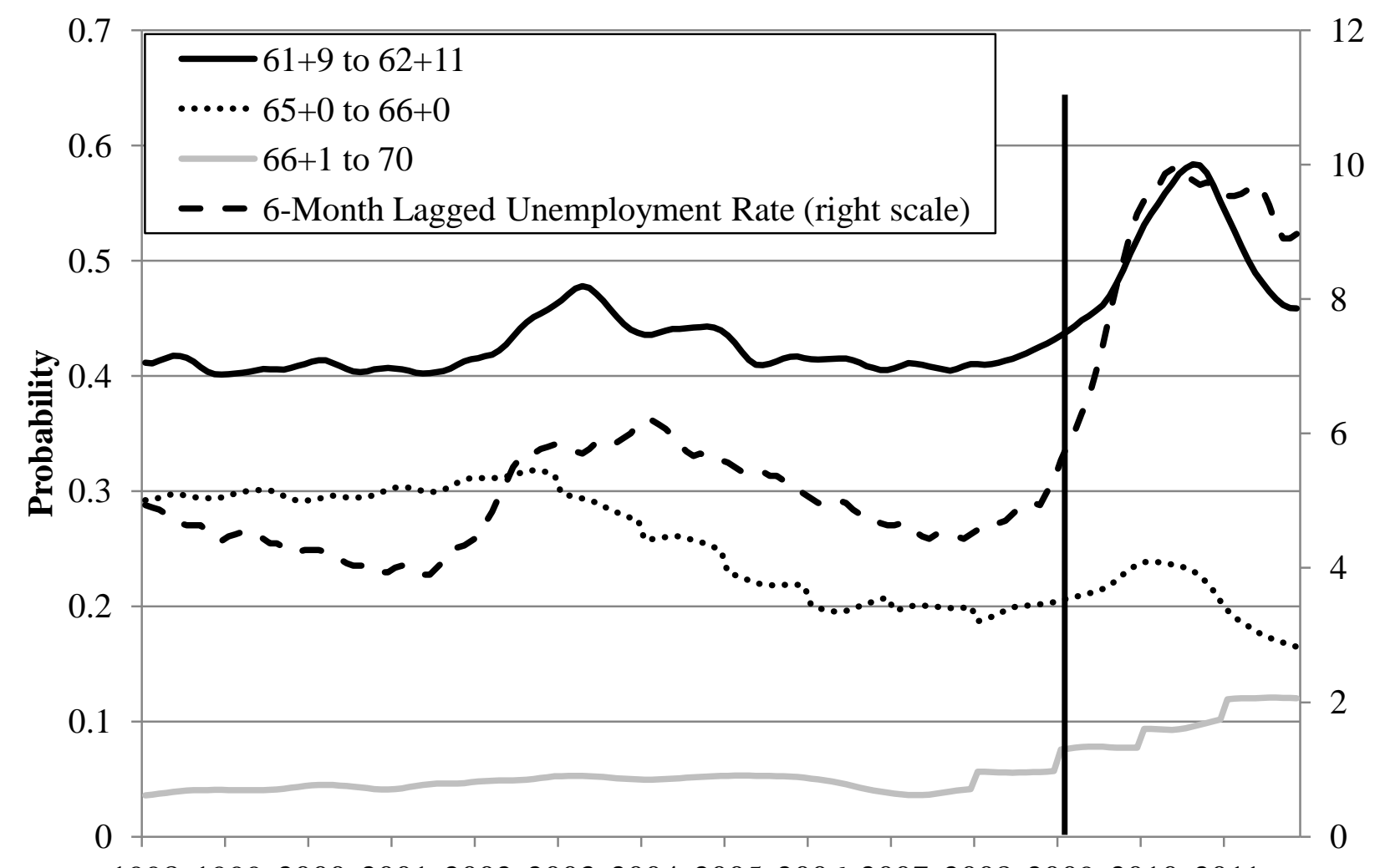

19981999200020012002200320042005200620072008200920102011

Source: Authors' estimates using Health and Retirement Study 1996-2008. 
Figure 4. Predicted Probability of Claiming Early across Household Income Distribution

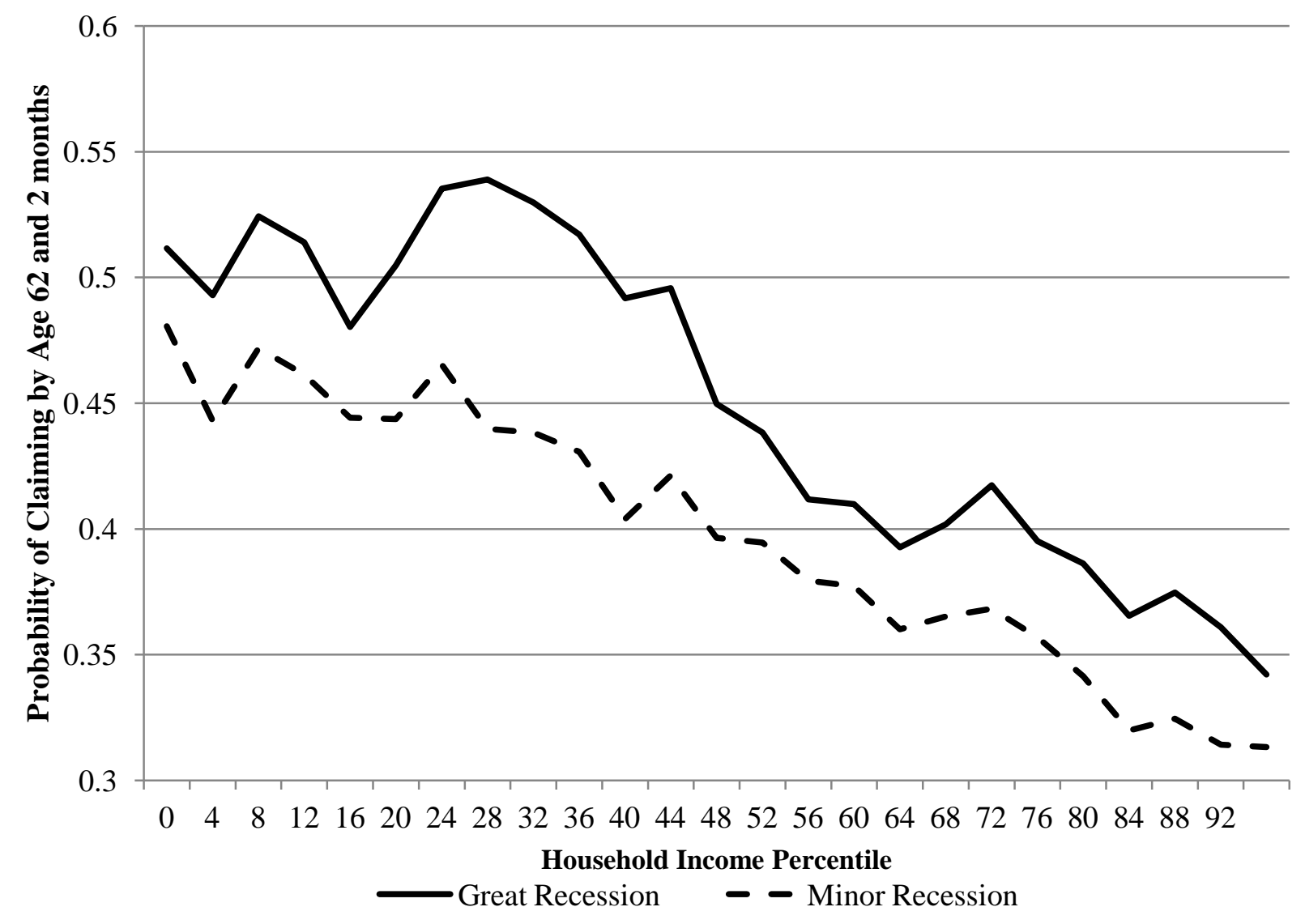

Source: Authors' simulations using Health and Retirement Study 1996-2008. 
Figure 5. Predicted Probability of Claiming Early across Household Wealth Distribution

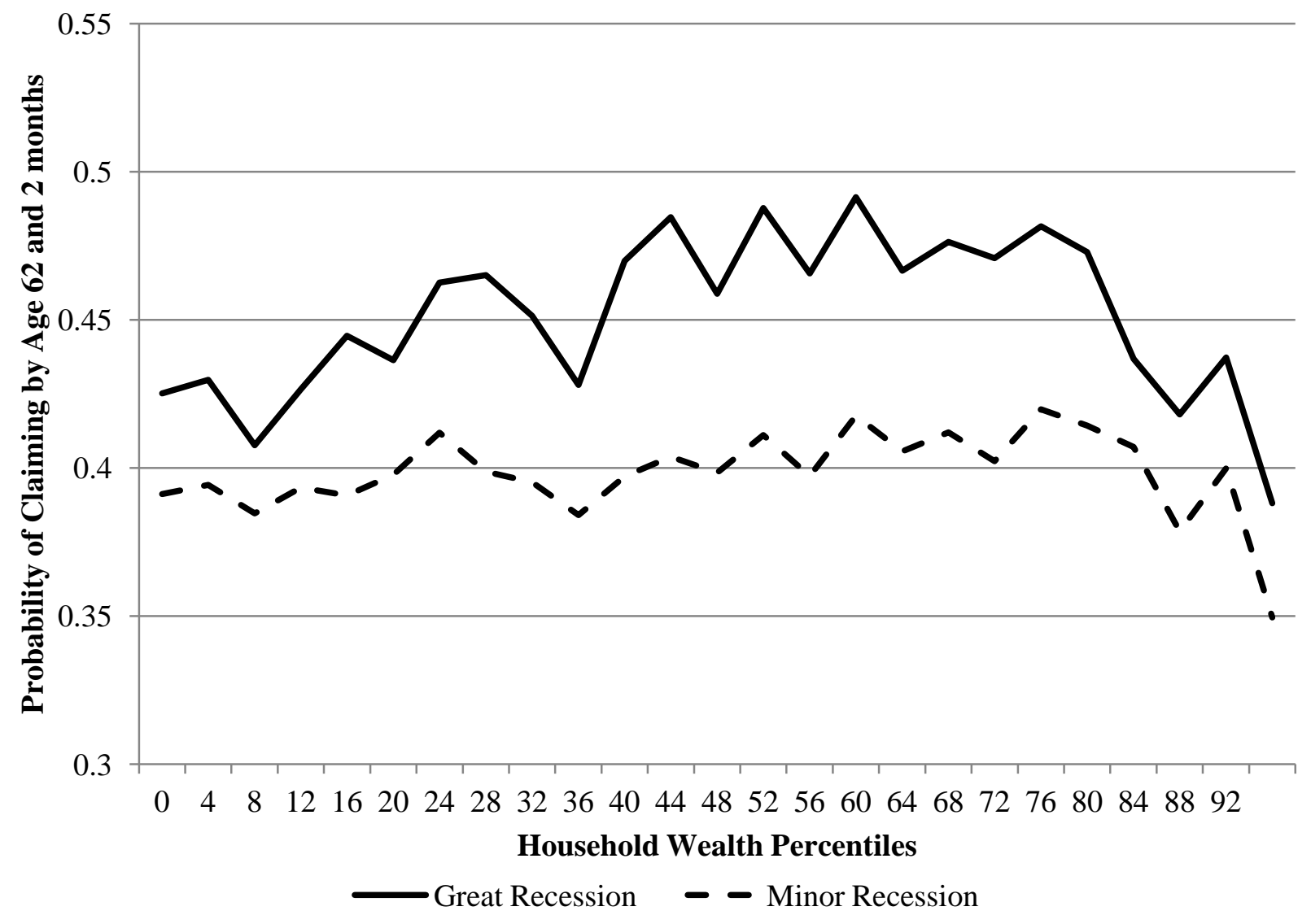

Source: Authors' simulations using Health and Retirement Study 1996-2008. 
Table 1. Sample Refinement

\begin{tabular}{lr}
\hline & Sample size \\
\hline Beginning sample & 8193 \\
Reported getting SSDI & -641 \\
Eligible for SSDI & -71 \\
Unable to determine whether SSDI or SSI & -352 \\
No earnings history & -705 \\
Claimed to receive benefits before 62 & -841 \\
Claimed to receive benefits, but did not know when & -301 \\
Did not report receiving benefit and are not eligible & -172 \\
Receiving Social Security after turning 61 years old and 9 & \\
months, but did not work 40 quarters & -156 \\
Not observed between 61 years 9 months and 70 years old & -1432 \\
\hline$\quad$ Hazard Model Sample & 3522 \\
$\quad$ Claimed benefits at some point & \\
$\quad$ Don't know if or when they claimed & \\
Did not turn 62 between 1998 and 2008 & -285 \\
\hline Sample for Probit Model for Claiming at 62 & 3237 \\
$\quad$ Claimed benefits at 62 & \\
$\quad$ Did not claim benefits at 62 & \\
Don't know if or when they claimed & \\
\hline
\end{tabular}

Source: Authors' calculations from the Health and Retirement Study 1996-2008. 
Table 2. Means by Claiming Age

\begin{tabular}{lccc} 
& \multicolumn{3}{c}{ Claimed at: } \\
\cline { 2 - 3 } & $61+9$ to $62+2$ & $62+3$ to FRA & FRA and older \\
\hline Female & 55.20 & 51.44 & 44.05 \\
Married (0/1) & 79.35 & 76.34 & 71.59 \\
Hispanic (0/1) & 7.89 & 8.17 & 7.49 \\
Non-White (0/1) & 13.51 & 14.79 & 13.88 \\
Pr(Live until 75) & 82.85 & 82.27 & 90.14 \\
More than 2 ADLs (0/1) & 26.85 & 25.06 & 16.52 \\
Spouse Working (0/1) & 42.20 & 48.33 & 49.12 \\
Spouse Age at Claiming (among married) (0/1) & & \\
$\quad$ Under Age 62 & 46.31 & 50.58 & 51.76 \\
$\quad$ 62 to FRA & 22.57 & 18.68 & 13.66 \\
$\quad$ FRA or Older & 13.34 & 9.88 & 7.49 \\
Education (0/1) & & & 11.01 \\
$\quad$ Less than HS & 18.04 & 16.65 & 29.07 \\
$\quad$ HS Diploma Only & 43.29 & 36.34 & 22.47 \\
$\quad$ Some College & 22.06 & 23.19 & 37.44 \\
$\quad$ College or More & 16.61 & 23.81 & 115,544 \\
Household Income & 56,711 & 62,515 & 418,016 \\
Household Wealth & 308,969 & 347,831 & 12.33 \\
Pension (0/1) & & & 18.94 \\
$\quad$ DB Only & 18.54 & 15.72 & 43.83 \\
$\quad$ DC Only & 13.51 & 14.40 & 19.60 \\
$\quad$ Both & 34.82 & 42.49 & 5.29 \\
$\quad$ No pension & 30.79 & 22.33 & 454 \\
N/A & 2.35 & 5.06 & \\
Sample size & & & \\
\hline
\end{tabular}

Source: Authors' calculations from the Health and Retirement Study 1996-2008. 
Table 3. Means for Early Claimers, by Business Cycle

\begin{tabular}{|c|c|c|c|}
\hline & \multicolumn{3}{|c|}{ Claimed at 62 in: } \\
\hline & $1998-2000$ & $2001-2003$ & $2004-2008$ \\
\hline Female & 53.6 & 51.9 & 60.8 \\
\hline Married (0/1) & 81.7 & 76.5 & 80.4 \\
\hline Hispanic $(0 / 1)$ & 8.0 & 8.9 & 6.5 \\
\hline Non-White $(0 / 1)$ & 13.4 & 13.9 & 13.2 \\
\hline $\operatorname{Pr}($ Live until 75) & 81.4 & 87.2 & 79.1 \\
\hline $\operatorname{Pr}($ Live until 75) N/A (0/1) & 11.0 & 9.6 & 8.9 \\
\hline More than 2 ADLs (0/1) & 23.1 & 27.5 & 29.8 \\
\hline Worked FT pre-62 (0/1) & 39.1 & 36.0 & 29.8 \\
\hline Worked PT pre-62 (0/1) & 10.5 & 11.2 & 14.2 \\
\hline Spouse Working $(0 / 1)$ & 44.0 & 40.0 & 43.0 \\
\hline \multicolumn{4}{|l|}{ Spouse Age (among married) (0/1) } \\
\hline Under Age 62 & 48.3 & 49.2 & 40.9 \\
\hline 62 to FRA & 20.9 & 20.6 & 26.6 \\
\hline FRA or Older & 15.0 & 11.4 & 14.0 \\
\hline \multicolumn{4}{|l|}{ Industry $(0 / 1)$} \\
\hline N/A & 41.6 & 43.8 & 47.3 \\
\hline Agriculture & 2.4 & 1.6 & 2.2 \\
\hline Professional & 13.9 & 15.4 & 13.4 \\
\hline Manufacturing & 17.4 & 13.6 & 11.8 \\
\hline Services & 14.7 & 17.7 & 15.6 \\
\hline Business & 9.9 & 7.8 & 9.7 \\
\hline \multicolumn{4}{|l|}{ Education (0/1) } \\
\hline Less than HS & 19.0 & 20.1 & 14.5 \\
\hline High School Degree Only & 47.5 & 39.1 & 44.1 \\
\hline Some College & 20.1 & 23.7 & 22.0 \\
\hline College or More & 13.4 & 17.0 & 19.4 \\
\hline \multicolumn{4}{|l|}{ Income $(0 / 1)$} \\
\hline 1st Quintile & 30.0 & 32.7 & 29.3 \\
\hline 2nd Quintile & 24.7 & 24.6 & 21.0 \\
\hline 3rd Quintile & 20.6 & 20.1 & 18.0 \\
\hline 4th Quintile & 13.9 & 15.2 & 20.2 \\
\hline 5th Quintile & 10.7 & 7.4 & 11.6 \\
\hline \multicolumn{4}{|l|}{ Wealth $(0 / 1)$} \\
\hline 1st Quintile & 14.5 & 22.8 & 18.8 \\
\hline 2nd Quintile & 21.7 & 22.4 & 22.6 \\
\hline 3rd Quintile & 18.0 & 20.1 & 18.8 \\
\hline 4th Quintile & 21.4 & 18.6 & 23.7 \\
\hline 5th Quintile & 24.4 & 16.1 & 16.1 \\
\hline \multicolumn{4}{|l|}{ Pension (0/1) } \\
\hline DB Only & 20.4 & 18.8 & 16.4 \\
\hline DC Only & 12.9 & 11.2 & 16.9 \\
\hline Both & 28.7 & 38.5 & 36.6 \\
\hline None & 35.4 & 29.1 & 28.2 \\
\hline N/A & 2.7 & 2.5 & 1.9 \\
\hline \multicolumn{4}{|l|}{ Tenure at Last Job (0/1) } \\
\hline 0 to 5 Years & 22.5 & 23.5 & 26.6 \\
\hline 5 to 10 Years & 7.5 & 10.7 & 8.1 \\
\hline 10 or More Years & 28.7 & 22.6 & 20.2 \\
\hline N/A & 41.3 & 43.2 & 45.2 \\
\hline Sample size & 373 & 447 & 372 \\
\hline
\end{tabular}

Source: Authors' calculations from the Health and Retirement Study 1996-2008. 
Table 4. Results for Probit Regression of Claiming at Age 62

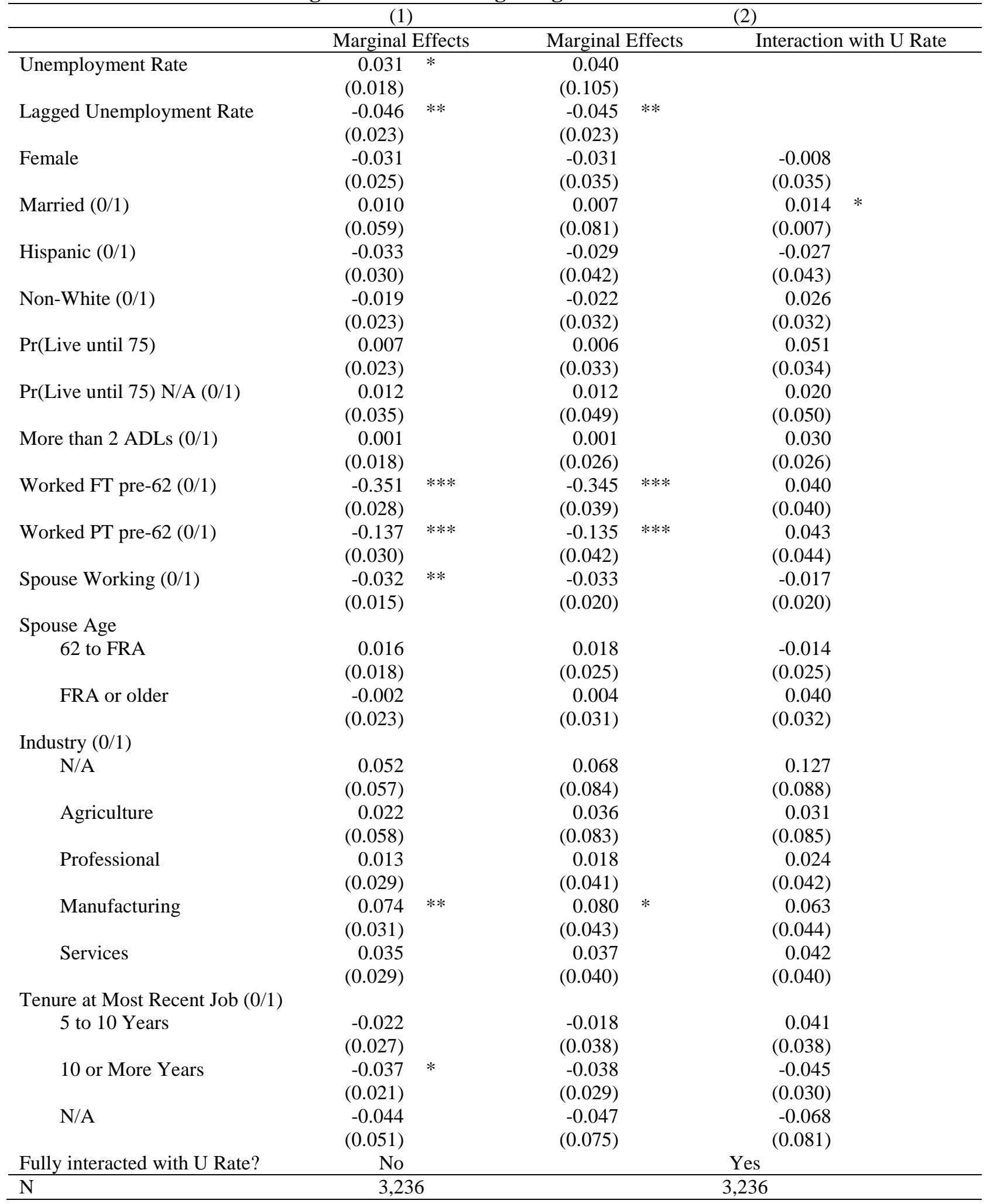

Note: In both specifications, female and the education and wealth categories are also interacted with marital status.

*** - Significantly different from zero at the 99 percent confidence level ** - 95 percent * - 90 percent

Source: Authors' calculations from the Health and Retirement Study 1996-2008. 
Table 4 (cont). Results for Probit Regression of Claiming at Age 62

\begin{tabular}{|c|c|c|c|c|c|}
\hline & \multicolumn{2}{|c|}{$(1)$} & \multicolumn{3}{|c|}{$(2)$} \\
\hline & Marginal & Effects & Marginal & ffects & Interaction with U Rate \\
\hline \multicolumn{6}{|l|}{ Education (0/1) } \\
\hline \multirow[t]{2}{*}{ Less than HS } & 0.007 & & 0.009 & & 0.059 \\
\hline & $(0.033)$ & & $(0.046)$ & & $(0.046)$ \\
\hline \multirow[t]{2}{*}{ Some College } & -0.040 & & -0.039 & & 0.031 \\
\hline & $(0.028)$ & & $(0.038)$ & & $(0.038)$ \\
\hline \multirow[t]{2}{*}{ College or More } & -0.130 & $* * *$ & -0.126 & $* * *$ & 0.040 \\
\hline & $(0.028)$ & & $(0.039)$ & & $(0.039)$ \\
\hline \multicolumn{6}{|l|}{ Income (0/1) } \\
\hline \multirow[t]{2}{*}{ 1st Quintile } & 0.062 & $* *$ & 0.066 & * & 0.034 \\
\hline & $(0.027)$ & & $(0.038)$ & & $(0.038)$ \\
\hline \multirow[t]{2}{*}{ 2nd Quintile } & 0.036 & & 0.040 & & 0.029 \\
\hline & $(0.025)$ & & $(0.035)$ & & $(0.035)$ \\
\hline \multirow[t]{2}{*}{ 4th Quintile } & -0.017 & & -0.014 & & 0.038 \\
\hline & $(0.025)$ & & $(0.035)$ & & $(0.035)$ \\
\hline \multirow[t]{2}{*}{ 5th Quintile } & -0.108 & $* * *$ & -0.103 & $* * *$ & -0.043 \\
\hline & $(0.027)$ & & $(0.037)$ & & $(0.038)$ \\
\hline \multicolumn{6}{|l|}{ Wealth (0/1) } \\
\hline \multirow[t]{2}{*}{ 1st Quintile } & -0.018 & & -0.019 & & 0.015 \\
\hline & $(0.036)$ & & $(0.049)$ & & $(0.049)$ \\
\hline \multirow[t]{2}{*}{ 2nd Quintile } & 0.016 & & 0.016 & & 0.043 \\
\hline & $(0.034)$ & & $(0.047)$ & & $(0.047)$ \\
\hline \multirow{2}{*}{ 4th Quintile } & 0.063 & * & 0.054 & & 0.038 \\
\hline & $(0.037)$ & & $(0.051)$ & & $(0.052)$ \\
\hline \multirow[t]{2}{*}{ 5th Quintile } & 0.051 & & 0.049 & & -0.009 \\
\hline & $(0.041)$ & & $(0.056)$ & & $(0.056)$ \\
\hline \multicolumn{6}{|l|}{ Pension } \\
\hline \multirow[t]{2}{*}{ DB Only } & 0.037 & & 0.041 & & -0.051 \\
\hline & $(0.026)$ & & $(0.036)$ & & $(0.036)$ \\
\hline \multirow[t]{2}{*}{ DC Only } & -0.002 & & 0.000 & & -0.022 \\
\hline & $(0.026)$ & & $(0.036)$ & & $(0.037)$ \\
\hline \multirow[t]{2}{*}{ Both } & 0.008 & & 0.011 & & -0.014 \\
\hline & $(0.022)$ & & $(0.031)$ & & $(0.031)$ \\
\hline \multirow[t]{2}{*}{ N/A } & -0.116 & $* * *$ & -0.117 & $* *$ & -0.021 \\
\hline & $(0.039)$ & & $(0.055)$ & & $(0.057)$ \\
\hline Fully interacted with U Rate? & \multicolumn{2}{|c|}{ No } & \multicolumn{3}{|c|}{ Yes } \\
\hline $\mathrm{N}$ & \multirow{2}{*}{\multicolumn{2}{|c|}{$\begin{array}{l}3,839 \\
0.093\end{array}$}} & \multirow{2}{*}{\multicolumn{3}{|c|}{3,839}} \\
\hline Pseudo-R2 & & & & & \\
\hline
\end{tabular}

Note: In both specifications, female and the education and wealth categories are also interacted with marital status. *** - Significantly different from zero at the 99 percent confidence level ** - 95 percent confidence level * - 90 percent confidence level

Source: Authors' calculations from the Health and Retirement Study 1996-2008. 
Table 5. Social Security Benefit Claiming Hazard Model Results

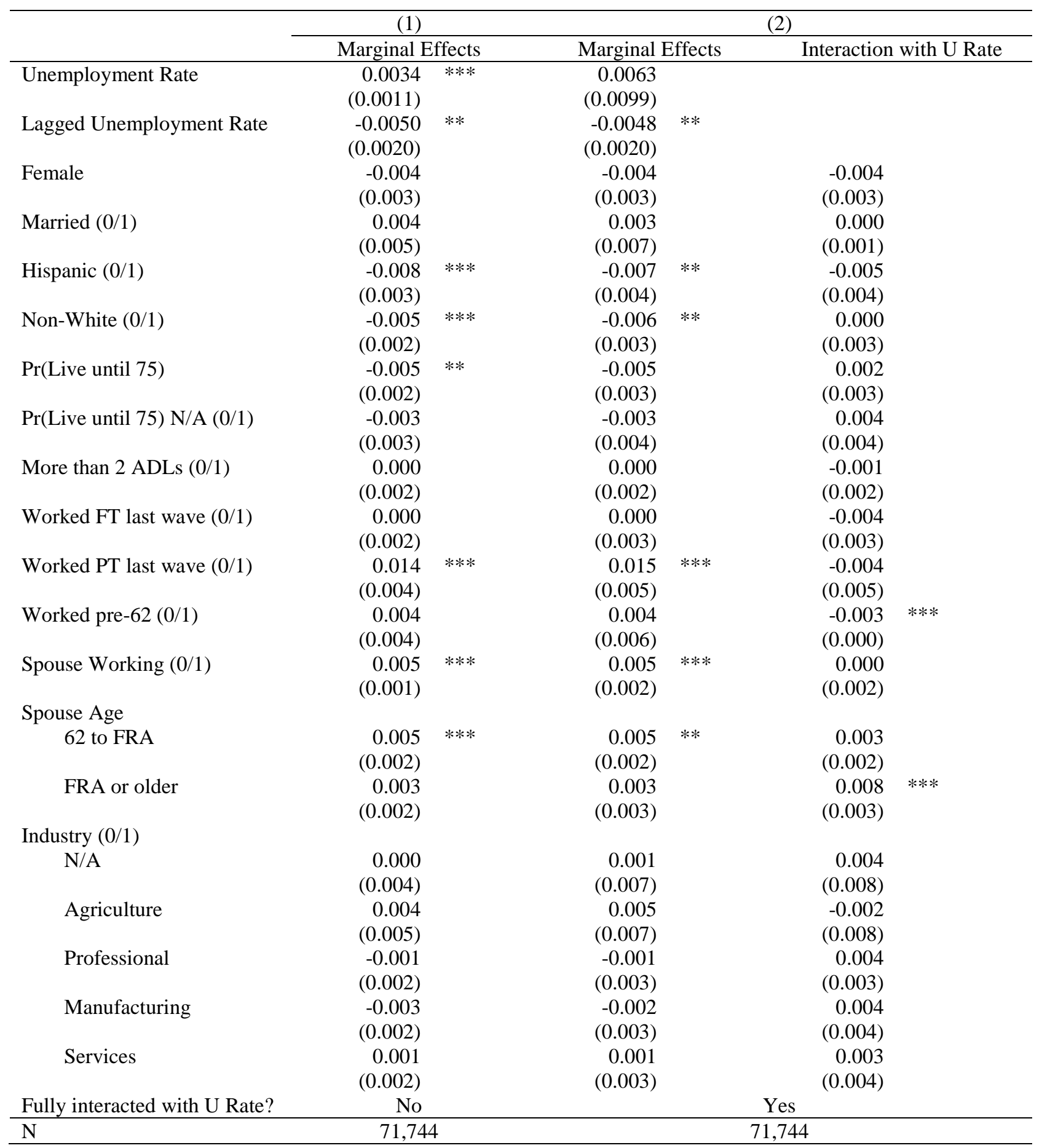

Note: In both specifications, female and the education and wealth categories are also interacted with marital status, and wealth is interacted with pre-62 work status.

*** - Significantly different from zero at the 99 percent confidence level ** - 95 percent * - 90 percent

Source: Authors' estimates from the Health and Retirement Study 1996-2008. 
Table 5 (cont). Social Security Benefit Claiming Hazard Model Results

\begin{tabular}{|c|c|c|c|c|c|c|}
\hline \multirow{3}{*}{ Tenure at Most Recent Job (0/1) } & \multirow{2}{*}{\multicolumn{2}{|c|}{$\begin{array}{c}(1) \\
\text { Marginal Effects }\end{array}$}} & \multicolumn{4}{|c|}{ (2) } \\
\hline & & & \multicolumn{2}{|c|}{ Marginal Effects } & \multicolumn{2}{|c|}{ Interaction with U Rate } \\
\hline & & & & & & \\
\hline 5 to 10 Years & $\begin{array}{r}-0.005 \\
(0.002)\end{array}$ & $* *$ & $\begin{array}{r}-0.005 \\
(0.003)\end{array}$ & $*$ & $\begin{array}{r}0.002 \\
(0.003)\end{array}$ & \\
\hline 10 or More Years & $\begin{array}{r}-0.007 \\
(0.002)\end{array}$ & $* * *$ & $\begin{array}{r}-0.008 \\
(0.002)\end{array}$ & $* * *$ & $\begin{array}{r}-0.002 \\
(0.003)\end{array}$ & \\
\hline N/A & $\begin{array}{r}0.036 \\
(0.007)\end{array}$ & $* * *$ & $\begin{array}{r}0.035 \\
(0.011)\end{array}$ & $* * *$ & $\begin{array}{r}-0.004 \\
(0.012)\end{array}$ & \\
\hline \multicolumn{7}{|l|}{ Education (0/1) } \\
\hline Less than HS & $\begin{array}{r}0.002 \\
(0.003)\end{array}$ & & $\begin{array}{r}0.002 \\
(0.005)\end{array}$ & & $\begin{array}{r}0.001 \\
(0.004)\end{array}$ & \\
\hline Some College & $\begin{array}{r}-0.002 \\
(0.003)\end{array}$ & & $\begin{array}{r}-0.002 \\
(0.004)\end{array}$ & & $\begin{array}{r}0.006 \\
(0.004)\end{array}$ & $*$ \\
\hline College or More & $\begin{array}{r}-0.014 \\
(0.002)\end{array}$ & $* * *$ & $\begin{array}{r}-0.014 \\
(0.003)\end{array}$ & $* * *$ & $\begin{array}{r}0.005 \\
(0.003)\end{array}$ & \\
\hline \multicolumn{7}{|l|}{ Income $(0 / 1)$} \\
\hline 1st Quintile & $\begin{array}{r}0.015 \\
(0.003)\end{array}$ & $* * *$ & $\begin{array}{r}0.015 \\
(0.004)\end{array}$ & $* * *$ & $\begin{array}{r}0.006 \\
(0.004)\end{array}$ & \\
\hline 2nd Quintile & $\begin{array}{r}0.003 \\
(0.002)\end{array}$ & & $\begin{array}{r}0.004 \\
(0.003)\end{array}$ & & $\begin{array}{r}0.009 \\
(0.004)\end{array}$ & $* *$ \\
\hline 4th Quintile & $\begin{array}{r}-0.006 \\
(0.002)\end{array}$ & $* * *$ & $\begin{array}{r}-0.005 \\
(0.003)\end{array}$ & $*$ & $\begin{array}{r}0.001 \\
(0.003)\end{array}$ & \\
\hline 5th Quintile & $\begin{array}{r}-0.013 \\
(0.002)\end{array}$ & $* * *$ & $\begin{array}{r}-0.013 \\
(0.003)\end{array}$ & $* * *$ & $\begin{array}{r}0.000 \\
(0.003)\end{array}$ & \\
\hline \multicolumn{7}{|l|}{ Wealth (0/1) } \\
\hline 1st Quintile & $\begin{array}{r}-0.001 \\
(0.004)\end{array}$ & & $\begin{array}{r}-0.001 \\
(0.006)\end{array}$ & & $\begin{array}{r}-0.003 \\
(0.006)\end{array}$ & \\
\hline 2nd Quintile & $\begin{array}{r}-0.003 \\
(0.004)\end{array}$ & & $\begin{array}{r}-0.003 \\
(0.005)\end{array}$ & & $\begin{array}{r}-0.002 \\
(0.005)\end{array}$ & \\
\hline 4th Quintile & $\begin{array}{r}0.006 \\
(0.004)\end{array}$ & & $\begin{array}{r}0.006 \\
(0.006)\end{array}$ & & $\begin{array}{r}-0.001 \\
(0.007)\end{array}$ & \\
\hline 5th Quintile & $\begin{array}{r}0.006 \\
(0.005)\end{array}$ & & $\begin{array}{r}0.006 \\
(0.007)\end{array}$ & & $\begin{array}{r}-0.006 \\
(0.007)\end{array}$ & \\
\hline \multicolumn{7}{|l|}{ Pension } \\
\hline DB Only & $\begin{array}{r}0.007 \\
(0.003)\end{array}$ & $* *$ & $\begin{array}{r}0.008 \\
(0.004)\end{array}$ & $*$ & $\begin{array}{r}0.000 \\
(0.004)\end{array}$ & \\
\hline DC Only & $\begin{array}{r}0.005 \\
(0.003)\end{array}$ & $*$ & $\begin{array}{r}0.005 \\
(0.004)\end{array}$ & & $\begin{array}{r}0.002 \\
(0.004)\end{array}$ & \\
\hline Both & $\begin{array}{r}0.008 \\
(0.002)\end{array}$ & $* * *$ & $\begin{array}{r}0.009 \\
(0.003)\end{array}$ & $* * *$ & $\begin{array}{r}0.002 \\
(0.003)\end{array}$ & \\
\hline N/A & $\begin{array}{r}0.004 \\
(0.004)\end{array}$ & & $\begin{array}{r}0.005 \\
(0.006)\end{array}$ & & $\begin{array}{r}0.005 \\
(0.006)\end{array}$ & \\
\hline Full Retirement Age or later (0/1) & $\begin{array}{r}0.058 \\
(0.010)\end{array}$ & $* * *$ & $\begin{array}{r}0.059 \\
(0.012)\end{array}$ & $* * *$ & $\begin{array}{r}0.006 \\
(0.009)\end{array}$ & \\
\hline Fully interacted with U Rate? & No & & & & & \\
\hline $\mathrm{N}$ & 71,744 & & & & & \\
\hline Pseudo-R2 & 0.168 & & & & & \\
\hline
\end{tabular}


Table 6. Simulated Percent Claiming by Age under Three Macroeconomic Scenarios

\begin{tabular}{lccc}
\hline & \multicolumn{3}{c}{ Percent Claiming by Age } \\
\cline { 2 - 4 } & $61+9-62+2$ & $62+3-($ FRA-3) & (FRA-2) or later \\
\cline { 2 - 4 } Great Recession & 46.5 & 50.0 & 3.8 \\
Minor Recession & 40.9 & 55.5 & 3.9 \\
No Recession & 38.3 & 57.8 & 4.1 \\
\hline
\end{tabular}

Source: Authors' simulations using Health and Retirement Study 1996-2008. 
Table 7. Means for Always and Great Recession Claimers

\begin{tabular}{|c|c|c|c|}
\hline & \multicolumn{2}{|c|}{$\begin{array}{l}\text { Projected Probability } \\
\text { of Claiming Early } \\
\text { in... }\end{array}$} & \multirow[b]{3}{*}{ Difference } \\
\hline & Minor & Great & \\
\hline & Recession & Recession & \\
\hline Female & 41.6 & 46.6 & 5.0 \\
\hline Male & 40.2 & 46.3 & 6.1 \\
\hline Married & 41.4 & 46.7 & 5.3 \\
\hline Unmarried & 39.3 & 45.8 & 6.5 \\
\hline Hispanic & 36.8 & 39.7 & 2.9 \\
\hline Non-Hispanic & 41.2 & 47.0 & 5.8 \\
\hline Non-White & 38.4 & 44.2 & 5.8 \\
\hline White & 41.3 & 46.9 & 5.5 \\
\hline \multicolumn{4}{|l|}{ Pr(Live until 75) } \\
\hline Less than 1 & 42.5 & 48.8 & 6.3 \\
\hline 1 or More & 41.5 & 46.4 & 4.9 \\
\hline N/A & 40.1 & 46.6 & 6.5 \\
\hline More than 2 ADLs & 42.5 & 46.6 & 4.2 \\
\hline Fewer than 2 ADLs & 40.4 & 46.4 & 6.0 \\
\hline \multicolumn{4}{|l|}{ Income $(0 / 1)$} \\
\hline 1st Quintile & 46.6 & 50.7 & 4.1 \\
\hline 2nd Quintile & 46.5 & 57.4 & 10.9 \\
\hline 3rd Quintile & 38.9 & 42.0 & 3.1 \\
\hline 4th Quintile & 37.1 & 41.7 & 4.6 \\
\hline 5th Quintile & 32.5 & 37.1 & 4.6 \\
\hline \multicolumn{4}{|l|}{ Wealth $(0 / 1)$} \\
\hline 1st Quintile & 39.2 & 42.6 & 3.4 \\
\hline 2nd Quintile & 40.8 & 46.6 & 5.8 \\
\hline 3rd Quintile & 41.5 & 50.0 & 8.5 \\
\hline 4th Quintile & 43.1 & 49.7 & 6.6 \\
\hline 5th Quintile & 40.0 & 43.5 & 3.5 \\
\hline Working pre-62 & 35.4 & 40.4 & 5.0 \\
\hline Not Working pre-62 & 51.7 & 58.4 & 6.7 \\
\hline Spouse Working & 40.1 & 44.1 & 4.0 \\
\hline Spouse Not Working & 41.5 & 48.2 & 6.7 \\
\hline \multicolumn{4}{|l|}{ Spouse Age } \\
\hline Under Age 62 & 38.4 & 42.6 & 4.2 \\
\hline 62 to FRA & 43.9 & 48.2 & 4.3 \\
\hline FRA or Older & 49.1 & 60.7 & 11.6 \\
\hline Sample Size & 1325 & 1501 & \\
\hline
\end{tabular}

Source: Authors' simulations using the Health and Retirement Study 1996-2008. 
Table 7 (cont). Means for Always and Great Recession Claimers

\begin{tabular}{|c|c|c|c|}
\hline & \multicolumn{2}{|c|}{$\begin{array}{l}\text { Projected Probability of } \\
\text { Claiming Early in... }\end{array}$} & \multirow[b]{2}{*}{ Difference } \\
\hline & $\begin{array}{c}\text { Minor } \\
\text { Recession }\end{array}$ & $\begin{array}{c}\text { Great } \\
\text { Recession }\end{array}$ & \\
\hline \multicolumn{4}{|l|}{ Industry } \\
\hline N/A & 53.3 & 58.5 & 5.2 \\
\hline Agriculture & 35.4 & 36.7 & 1.2 \\
\hline Professional & 34.7 & 41.9 & 7.2 \\
\hline Manufacturing & 36.8 & 42.9 & 6.1 \\
\hline Services & 37.8 & 43.4 & 5.6 \\
\hline Business & 34.0 & 37.9 & 3.9 \\
\hline \multicolumn{4}{|l|}{ Education } \\
\hline Less than HS & 40.7 & 46.5 & 5.8 \\
\hline High School Degree & 40.5 & 48.2 & 7.7 \\
\hline Some College & 40.0 & 44.5 & 4.5 \\
\hline College or More & 42.5 & 47.0 & 4.5 \\
\hline \multicolumn{4}{|l|}{ Pension } \\
\hline DB Only & 40.8 & 46.6 & 5.8 \\
\hline DC Only & 41.1 & 46.6 & 5.5 \\
\hline Both & 41.3 & 46.3 & 5.0 \\
\hline None & 40.6 & 46.6 & 6.0 \\
\hline N/A & 40.9 & 46.3 & 5.4 \\
\hline \multicolumn{4}{|l|}{ Tenure at Last Job } \\
\hline 0 to 5 Years & 41.5 & 46.8 & 5.3 \\
\hline 5 to 10 Years & 41.5 & 46.6 & 5.1 \\
\hline 10 or More Years & 45.1 & 51.3 & 6.2 \\
\hline N/A & 35.9 & 41.8 & 5.9 \\
\hline Sample Size & 1,325 & 1,501 & \\
\hline
\end{tabular}


Table 8. Simulated Social Security Benefits and Claiming Ages under Three Macroeconomic Scenarios

\begin{tabular}{|c|c|c|c|}
\hline & \multicolumn{3}{|c|}{ Macroeconomic Assumption } \\
\hline & Great Recession & $\begin{array}{c}\text { Minor } \\
\text { Recession }\end{array}$ & No Recession \\
\hline \multicolumn{4}{|c|}{ Panel A: All Early Claimers in the Great Recession } \\
\hline Average Predicted Claiming Age & 62 yrs 11 mos & 63 yrs 1 mos & 63 yrs 3 mos \\
\hline Expected Monthly Social Security Benefit & $\$ 1,126$ & $\$ 1,150$ & $\$ 1,168$ \\
\hline Replacement Rate & $43.2 \%$ & $44.0 \%$ & $44.6 \%$ \\
\hline \multicolumn{4}{|l|}{ Panel B: All-Recession Claimers } \\
\hline Average Predicted Claiming Age & 62 yrs 11 mos & 63 yrs 1 mos & 63 yrs 3 mos \\
\hline Expected Monthly Social Security Benefit & $\$ 1,124$ & $\$ 1,142$ & $\$ 1,156$ \\
\hline Replacement Rate & $43.6 \%$ & $44.2 \%$ & $44.7 \%$ \\
\hline \multicolumn{4}{|l|}{ Panel C: Great Recession Claimers } \\
\hline Average Predicted Claiming Age & 62 yrs 8 mos & 63 yrs 2 mos & 63 yrs 6 mos \\
\hline Expected Monthly Social Security Benefit & $\$ 1,141$ & $\$ 1,196$ & $\$ 1,235$ \\
\hline Replacement Rate & $41.3 \%$ & $43.0 \%$ & $44.4 \%$ \\
\hline
\end{tabular}

Note: All-Recession Claimers are the group of individuals with at least 50 percent predicted probability of claiming by age 62 and 2 months under both the Great Recession and Minor Recession scenarios. Great Recession Claimers are the group of individuals with at least 50 percent predicted probability of claiming by age 62 and 2 months under the Great Recession, and less than 50 percent chance of claiming by age 62 and 2 months under the "minor recession" scenario.

Source: Authors' simulations using Health and Retirement Study 1996-2008. 
Table A1. Results for Probit Regression of Claiming at Age 62 by Gender and Marital Status

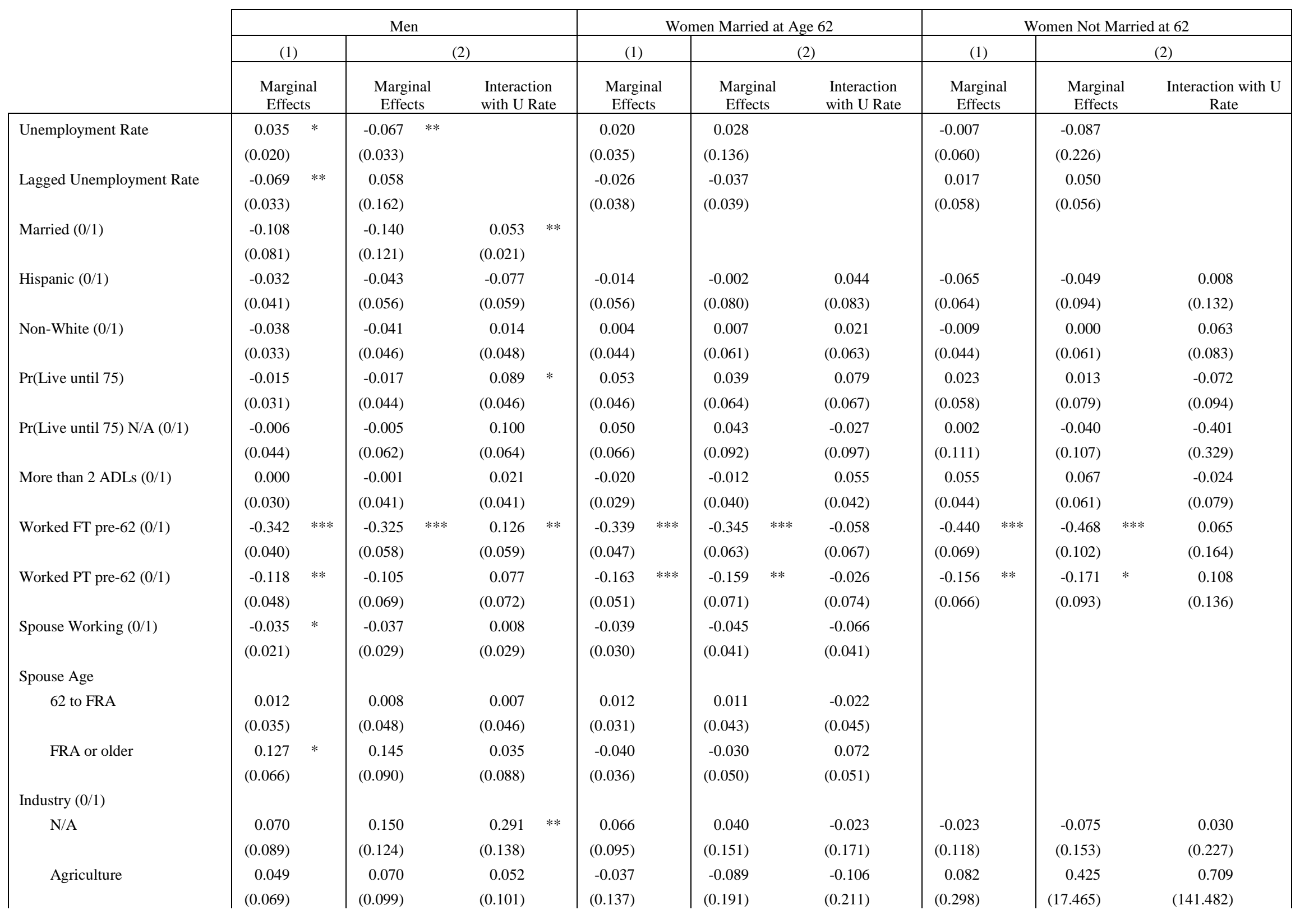




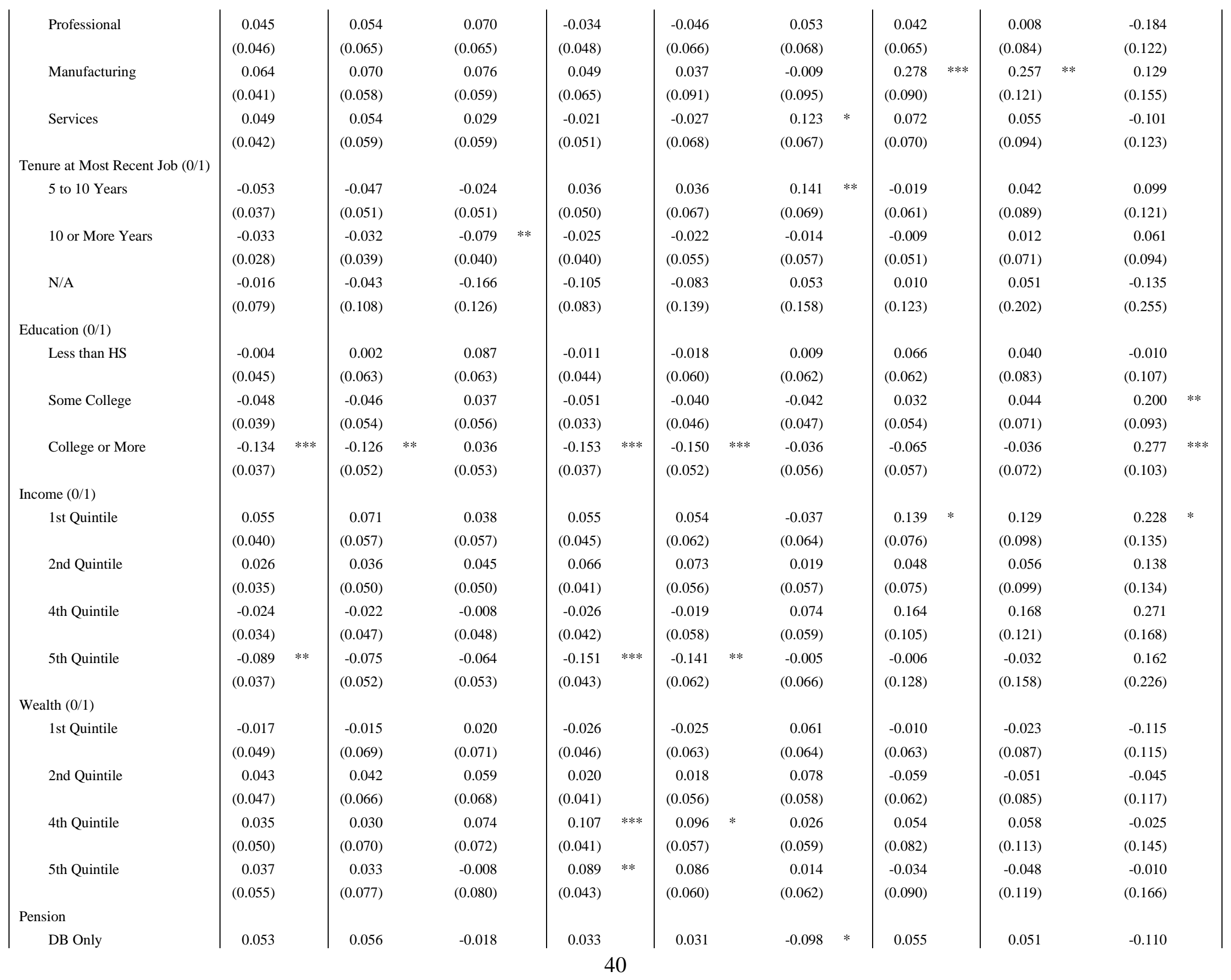




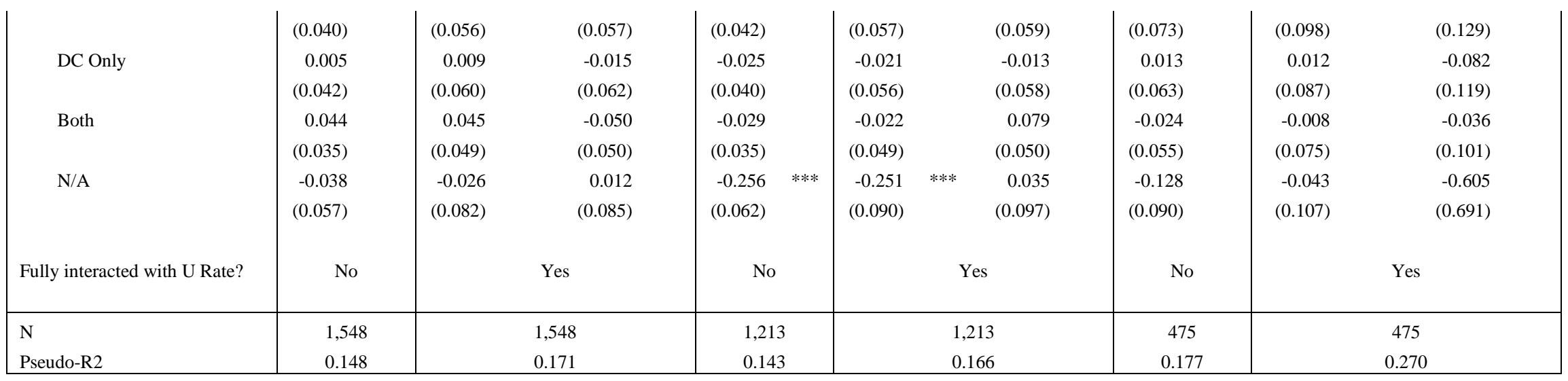

Note: In both specifications, female and the education and wealth categories are also interacted with marital status.

*** - Significantly different from zero at the 99 percent confidence level ** - 95 percent confidence level * - 90 percent confidence level

Source: Authors' estimates from the Health and Retirement Study 1996-2008. 
Table A2. Social Security Benefit Claiming Hazard Model Results by Gender and Marital Status

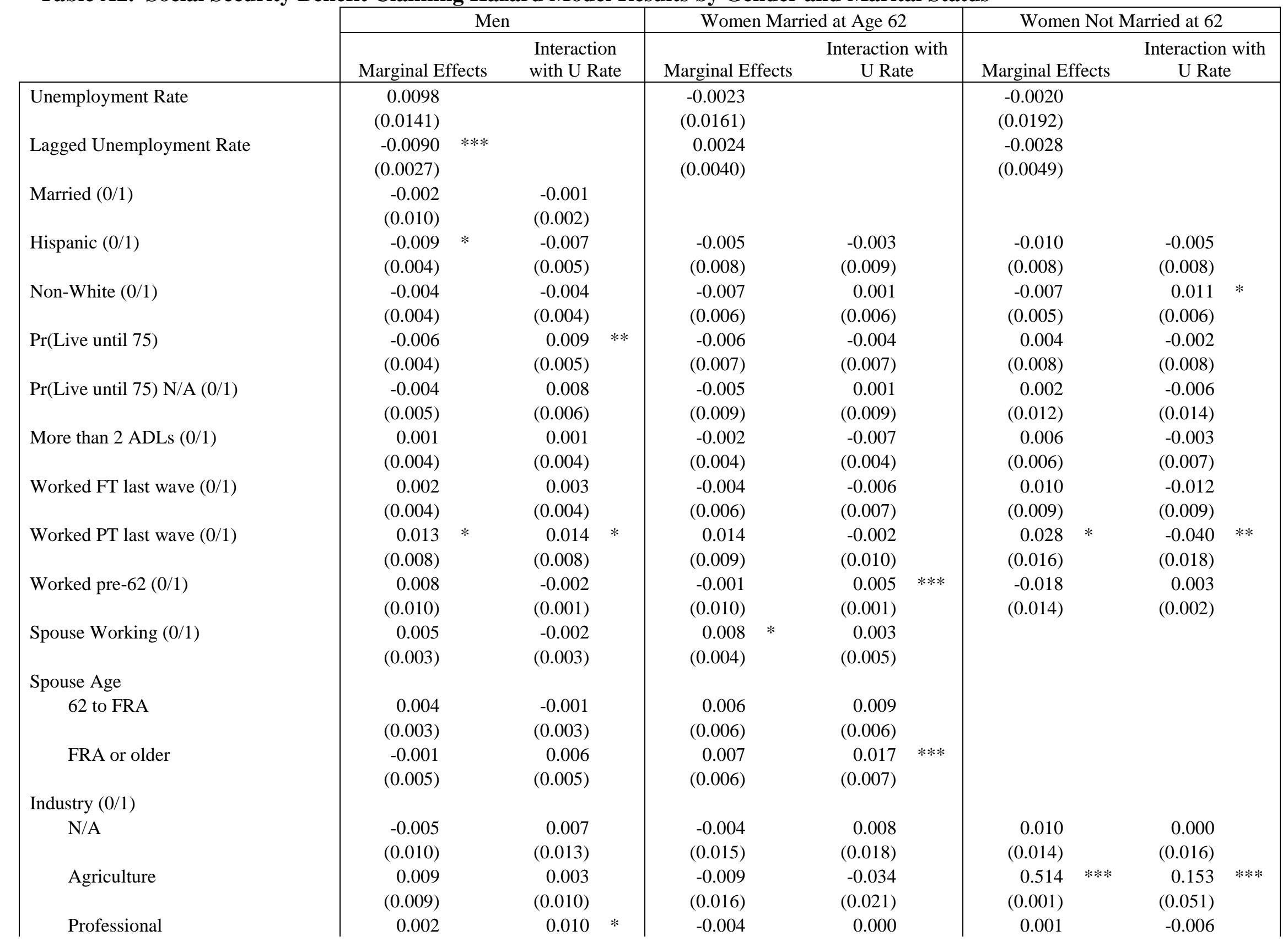




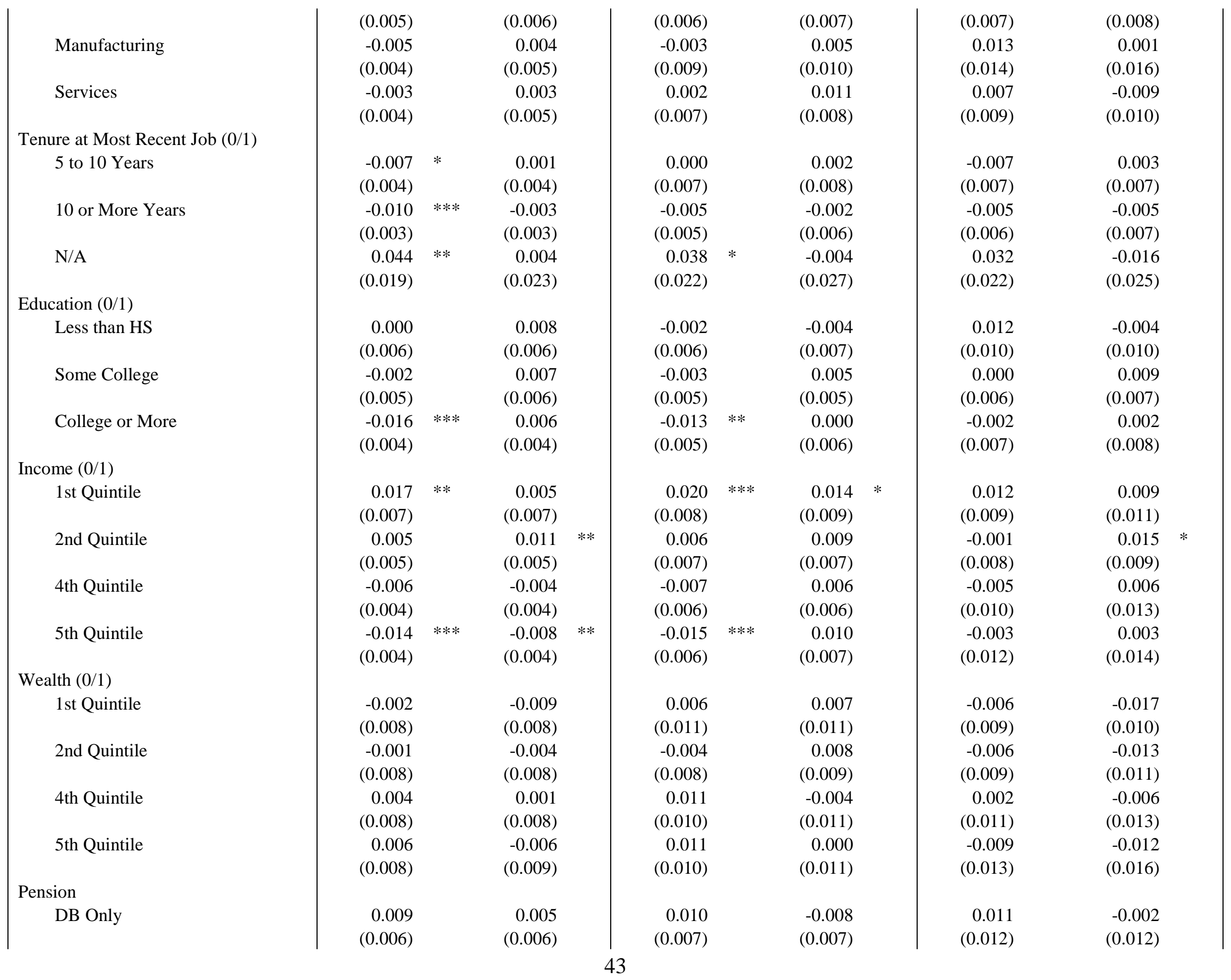




\begin{tabular}{|c|c|c|c|c|c|c|c|}
\hline DC Only & $\begin{array}{r}0.003 \\
(0.006)\end{array}$ & $\begin{array}{r}0.003 \\
(0.006)\end{array}$ & $\begin{array}{r}0.009 \\
(0.007)\end{array}$ & $\begin{array}{r}0.001 \\
(0.007)\end{array}$ & $\begin{array}{r}0.008 \\
(0.010)\end{array}$ & & $\begin{array}{r}0.002 \\
(0.012)\end{array}$ \\
\hline Both & 0.010 & 0.000 & 0.009 & 0.010 & 0.007 & & 0.005 \\
\hline & $(0.005)$ & $(0.005)$ & $(0.006)$ & $(0.006)$ & $(0.009)$ & & $(0.009)$ \\
\hline N/A & 0.009 & 0.003 & 0.004 & 0.005 & 0.008 & & 0.029 \\
\hline & $(0.008)$ & $(0.009)$ & $(0.010)$ & $(0.010)$ & $(0.018)$ & & $(0.024)$ \\
\hline Full Retirement Age or later $(0 / 1)$ & $\begin{array}{r}0.070 \\
(0.017)\end{array}$ & $\begin{array}{r}0.019 \\
(0.013)\end{array}$ & $\begin{array}{r}0.067 \\
(0.030)\end{array}$ & $\begin{array}{l}-0.021 \\
(0.025)\end{array}$ & $\begin{array}{r}0.089 \\
(0.029)\end{array}$ & $* * *$ & $\begin{array}{l}-0.020 \\
(0.026)\end{array}$ \\
\hline Fully interacted with U Rate? & \multicolumn{2}{|r|}{ Yes } & \multicolumn{2}{|r|}{ Yes } & \multicolumn{3}{|c|}{ Yes } \\
\hline $\begin{array}{l}\mathrm{N} \\
\text { Pseudo-R2 }\end{array}$ & \multicolumn{2}{|r|}{$\begin{array}{c}36,052 \\
0.184\end{array}$} & \multicolumn{2}{|r|}{$\begin{array}{c}22,278 \\
0.178\end{array}$} & \multicolumn{3}{|c|}{$\begin{array}{c}11,695 \\
0.178 \\
\end{array}$} \\
\hline
\end{tabular}

Note: In both specifications, female and the education and wealth categories are also interacted with marital status.

*** - Significantly different from zero at the 99 percent confidence level ** - 95 percent confidence level * - 90 percent confidence level

Source: Authors' calculations from the Health and Retirement Study 1996-2008. 


\section{RECENT WORKING PAPERS FROM THE CENTER FOR RETIREMENT RESEARCH AT BOSTON COLLEGE}

Effects of Employer Health Costs on the Trend and Distribution of Social Security-Taxable Wages

Gary Burtless And Sveta Milusheva, April 2012

Should Households Base Asset Decumulation Strategies on Required Minimum Distribution Tables?

Wei Sun and Anthony Webb, April 2012

Geographic Mobility Among Residents in Seniors Housing and Care Communities: Evidence from the Residents Financial Survey

Norma B. Coe and April Yanyuan Wu, April 2012

Costs and Concerns among Residents in Seniors Housing and Care Communities: Evidence from the Residents Financial Survey

Norma B. Coe and April Yanyuan Wu, April 2012

Financial Well-Being of Residents in Seniors Housing and Care Communities: Evidence from the Residents Financial Survey

Norma B. Coe and April Yanyuan Wu, April 2012

Residents in Senior Housing and Care Communities: Overview of the Residents Financial Survey

Norma B. Coe and April Yanyuan Wu, April 2012

Social Security Claiming: Trends and Business Cycle Effects

Owen Haaga and Richard W. Johnson, February 2012

Economic Consequences of the Great Recession: Evidence from the Panel Study of Income Dynamics

Barry Bosworth, February 2012

The Changing Causes and Consequences of Not Working Before Age 62

Barbara A. Butrica and Nadia Karamcheva, February 2012

The Impact of Temporary Assistance Programs on Disability Rolls and Re-Employment Stephan Lindner and Austin Nichols, January 2012

Understanding the Growth in Federal Disability Programs: Who Are the Marginal Beneficiaries, and How Much Do They Cost?

Adele Kirk, January 2012

All working papers are available on the Center for Retirement Research website (http://crr.bc.edu) and can be requested by e-mail (crr@bc.edu) or phone (617-552-1762). 